\title{
Effect of precalving and postcalving dietary energy level on performance and blood metabolite concentrations of dairy cows throughout lactation
}

\author{
R. A. Law, ${ }^{\star 1}$ F. J. Young, ${ }^{\star}$ D. C. Patterson, ${ }^{\star}$ D. J. Kilpatrick,† A. R. G. Wylie,† K. L. Ingvarsten,‡ A. Hameleers,§ \\ M. A. McCoy,† C. S. Mayne, ${ }^{\star}$ and C. P. Ferris* \\ *Agri-Food and Biosciences Institute, Agriculture Branch, Hillsborough, BT26 6DR, Northern Ireland \\ †Agri-Food and Biosciences Institute, Newforge Lane, Belfast, BT9 5PX, Northern Ireland \\ ‡Danish Institute of Agricultural Sciences, Department of Animal Health, Welfare and Nutrition, Research Centre Foulum, PO Box 50 , \\ 8830 Tjele, Denmark \\ §Embajada Real de Dinamarca, Casilla 9860, La Paz, Bolivia
}

\section{ABSTRACT}

The effects of the level of energy intake (high E and low E) offered before and after calving on body condition score at calving, production performance, and energy status in the first $250 \mathrm{~d}$ of lactation were evaluated in a $2 \times 2$ factorial design experiment involving 80 Holstein-Friesian dairy animals (40 primiparous and 40 multiparous). From d 80 until d 21 precalving, primiparous animals were offered either high or low pasture allowances. Thereafter, these animals were housed and had ad libitum access to a high energy density diet (high E) or restricted access [6 $\mathrm{kg}$ of dry matter (DM) per d] to a low energy density diet (low E), respectively, until calving. From d 100 until d 42 precalving, multiparous animals were offered either ad libitum or restricted (10 $\mathrm{kg}$ of $\mathrm{DM} / \mathrm{d}$ ) access to a late lactation diet, and thereafter, had ad libitum access to a high $\mathrm{E}$ diet or restricted access $(7 \mathrm{~kg}$ of DM complete diet/d) to a low E diet, respectively, until calving. The forage to concentrate $(\mathrm{F}: \mathrm{C})$ ratios (DM basis) of these high $\mathrm{E}$ and low $\mathrm{E}$ diets [d 42 (d 21 in primiparous animals) until calving] were 64:36 and 83:17, respectively. Cows offered high E and low $\mathrm{E}$ precalving diets were allocated to either a high $\mathrm{E}$ or low $\mathrm{E}$ postcalving diet $[\mathrm{F}: \mathrm{C}$ ratio (DM basis) of 30:70 and 70:30, respectively] and remained on these diets until d 250 of lactation. Multiparous animals offered a high $\mathrm{E}$ diet precalving had a significantly higher body condition score at calving than those offered the low $\mathrm{E}$ diet precalving. This effect was not evident in primiparous animals. Precalving diet had no significant effect on plasma nonesterified fatty acid concentrations during the last $3 \mathrm{wk}$ precalving in primi- or multiparous animals. Primiparous animals offered a high E diet precalving had significantly higher postcalving plasma concentrations of nonesterified fatty acid, suggest-

Received September 14, 2009.

Accepted October 15, 2010.

${ }^{1}$ Corresponding author: Ryan.Law@afbini.gov.uk ing greater mobilization of body reserves. Primi- and multiparous animals offered a high $\mathrm{E}$ diet postcalving had a significantly higher dry matter intake, milk yield, and energy status postcalving compared with animals offered a low E diet postcalving. Milk yields of primiparous animals offered high $\mathrm{E}$ and low $\mathrm{E}$ diets postcalving were 29.7 and $24.8 \mathrm{~kg} / \mathrm{d}$, respectively, and milk yield of multiparous animals offered high $\mathrm{E}$ and low $\mathrm{E}$ diets postcalving were 33.5 and $28.2 \mathrm{~kg} / \mathrm{d}$, respectively. It is concluded that altering body condition score during the dry period is difficult but that specific dietary regimens applied precalving can have a significant influence on postcalving production and energy-related parameters. Key words: precalving nutrition, milk yield, energy balance, plasma nonesterified fatty acids

\section{INTRODUCTION}

Intensive genetic selection for productivity has resulted in a dramatic increase in the milk production potential of the modern high-yielding dairy cow. However, in general, the observed increases in milk energy output in early lactation have not been matched by a proportionate increase in energy intake (Veerkamp et al.., 1995; Ingvarsten et al.., 1999). The resulting energy deficit [negative energy balance (NEB)] leads to a loss of body condition. A positive correlation between milk production potential and reductions in BCS during early lactation was previously demonstrated by Ruegg and Milton (1995). Severe and prolonged NEB may also predispose the animal to metabolic disorders, immunosuppression, and behavioral abnormalities, all of which can affect production, fertility, and the cow's general well-being (Nielsen, 1999). Reducing NEB and the accompanying BCS loss is likely to help minimize some of these problems.

Although the relationship between milk yield and DMI postcalving will influence the extent and the duration of NEB, both of these parameters will also be affected by BCS at calving. For example, BCS at calving 
has been positively correlated with the rate of BCS loss postcalving (Kokkonen et al., 2005), with fat animals having a greater energy deficit (lower intake relative to milk yield) in early lactation than thin animals. Friggens et al. (2004a) argued that the nutritional manipulation of cows to be either fatter or leaner than normal (BCS of 2.5 to 3.25) at calving provokes a change in the subsequent rate of BCS loss such that normal levels of body fatness are re-established approximately 3 to 4 mo after calving. This suggests the presence of a genetic component to postcalving BCS loss (Friggens et al., 2004a) and that the extent to which this is expressed is influenced by the difference between actual BCS at calving and that of the genetically desirable state. It may be that only when BCS loss exceeds this genetically predetermined rate, do dietary effects influence the energetic trajectory of these high-yielding animals. Garnsworthy and Topps (1982) demonstrated that a higher BCS at calving suppressed DMI after parturition, resulting in more severe NEB. This suggests that energy intake may be a response dictated by BCS loss. Thus, minimizing genetically driven BCS loss in early lactation by avoiding over-fat cows may alleviate the suppression of DMI and maximize the potential effect of postcalving nutrition in reducing BCS loss. Quantifying the effects of precalving nutrition on BCS at calving and subsequent effects on milk production, DMI, and BCS loss during lactation may allow a fuller understanding of factors affecting energetic responses to postcalving feeding strategies and more successful exploitation of such strategies.

Previous data on the effects of precalving nutrition on BCS at calving and subsequent postcalving performance are conflicting. Douglas et al. (2006) demonstrated that restricting DMI to $80 \%$ of requirements during the precalving period resulted in a lower BCS precalving and improved DMI postcalving. In support of this, Dann et al. (2006) identified significant effects of restricting DMI to $80 \%$ of requirements during the precalving period on postcalving energy balance, with a high plane of nutrition in the far-off period (between drying-off and $25 \mathrm{~d}$ before calving) resulting in more severe NEB in the first $10 \mathrm{~d}$ postcalving. However, the latter group noted no significant effect of precalving treatment on DMI or milk yield during the postcalving period. Furthermore, no significant effect of nutrition in the close-up period (from $24 \mathrm{~d}$ before calving until calving) on energy balance was observed during this period. Agenäs et al. (2003) found significant effects of precalving dietary energy intake $(71,106$, and 177 $\mathrm{MJ} / \mathrm{d}$ ) on BCS at calving but not on postcalving DMI, milk yield, or energy balance, and Winkelman et al. (2008) found no direct effects of precalving nutrition (feeding to requirement vs. ad libitum) on BCS preand postcalving or on energy balance postcalving.

The objective of the current study was to evaluate the effects of precalving nutrition on BCS at calving and on subsequent BCS loss during lactation. The study was also designed to evaluate the effect of preand postcalving nutrition and their interactions on feed intake, animal performance, and energy status during lactation.

\section{MATERIALS AND METHODS}

\section{Animals and Housing}

This experiment involved 80 Holstein-Friesian dairy animals [40 primiparous and 40 multiparous (mean parity, 3.2; SEM, 0.06)], calving between August 27 and December 21, 2004 (mean calving date October 16; SEM, 3.4). Primiparous refers to animals calving for the first time and multiparous refers to animals calving for the second time or greater. Primiparous animals were housed from $21 \mathrm{~d}$ before calving, whereas multiparous animals were housed for the entire duration of the precalving period. Primiparous animals were penned separately from multiparous animals in the same freestall house with concrete flooring. Following calving, all animals were housed as a single group in a freestall house with concrete flooring. The cubicle to cow ratio was $\geq 1: 1$ at all times, thus meeting the recommendations of FAWC (1997). Cubicles $(2.20 \times$ $1.25 \mathrm{~m}$ ) were fitted with rubber mats and bedded with sawdust thrice weekly. Concrete passageway floors were scraped at least 4 times daily by an automated system. Lights were left on in the cow house at all times.

\section{Experimental Design, Diets, and Feeding}

In the current experiment, treatments were in a 2 $\times 2$ factorial arrangement involving 2 levels of energy (E) intake (high $\mathrm{E}$ and low $\mathrm{E}$ ) precalving and 2 levels of energy intake (high E and low E) postcalving. Primiparous animals were assigned to precalving treatments in a balanced manner based on heifer rearing regimen, calving date, BCS, and BW. Multiparous animals were assigned to precalving treatments in a balanced manner according to parity, milk yield, calving date, BCS, and BW. From d 80 until d 21 precalving, primiparous animals were offered either high or low pasture allowances (25 or $10 \mathrm{~kg}$ of DM/animal per day, respectively, assessed above $5 \mathrm{~cm}$ cutting height). Thereafter, animals offered the high and low pasture allowances were housed and had ad libitum access to a high energy density diet (high E) and restricted access (6 $\mathrm{kg}$ of $\mathrm{DM} / \mathrm{d})$ to a low 
Table 1. Ingredient composition and chemical composition of the concentrate component of the diet offered in late lactation, during the dry period, and postcalving

\begin{tabular}{lccc}
\hline Constituent & $\begin{array}{c}\text { Late } \\
\text { lactation }\end{array}$ & $\begin{array}{c}\text { Dry } \\
\text { cow }^{1}\end{array}$ & Lactation \\
\hline Ingredient (g/kg, DM basis) & & & \\
Barley (milled) & 207 & 162 & 162 \\
Wheat (milled) & 207 & 162 & 162 \\
Unmolassed sugar beet pulp & 180 & 132 & 132 \\
Citrus pulp & 178 & 162 & 162 \\
Soybean meal (Hi-Pro) & 63 & 260 & 260 \\
Rape meal & 56 & 41 & 41 \\
Rumen-inert fat & 29 & 34 & 22 \\
Dairy cow minerals & 46 & 25 & 25 \\
Molasses & 34 & 13.1 & 13.1 \\
Chemical composition & & 220 & 220 \\
ME (MJ/kg of DM) & 12.8 & 109 & 109 \\
CP (g/kg of DM) & 136 & 217 & 217 \\
ADF (g/kg of DM) & 110 & 83.9 & 83.9 \\
NDF (g/kg of DM) & 211 & 218 & 218 \\
Ash (g/kg of DM) & 84.8 & 280 & \\
Starch (g/kg of DM) & & & 25 \\
\hline
\end{tabular}

${ }^{1}$ Dry cow mineral was added to dry cow diet at a level of $120 \mathrm{~g} /$ head per day; Trouw Nutrition (Belfast, UK).

${ }^{2}$ Megalac (Volac Ltd., Orwell, UK).

${ }^{3}$ Molaferm (United Molasses, Belfast, UK).

energy density diet (low E), respectively, until calving. Animals were fed individually and dietary restriction was achieved using electronic feeding gates (American Calan Inc., Northwood, NH), which were programmed to prevent individual animals gaining access to food after they had consumed their daily allocation of diet.

From d 100 to d 42 precalving (late lactation period), multiparous animals were offered either ad libitum or restricted $(10 \mathrm{~kg}$ of DM/d) access to a late-lactation diet. This was a complete diet with a forage to concentrate $(\mathbf{F}: \mathbf{C})$ ratio of $36: 64$. The forage component consisted of grass silage and maize silage (1:1 ratio; DM basis). Concentrate composition and analysis is presented in Table 1. From d 42 precalving (drying off) until calving, animals offered the ad libitum and restricted latelactation diets had ad libitum access to a high energy density diet (high E) and restricted access (7 kg of DM complete diet/d) to a low energy density diet (low E), respectively. The $\mathrm{F}: \mathrm{C}$ ratios (DM basis) of high $\mathrm{E}$ and low E diets [d 42 (d 21 in primiparous animals) until calving] were $64: 36$ and 83:17, respectively. Dietary restriction was achieved using electronic feeding gates as described previously. The forage component of both high $\mathrm{E}$ and low $\mathrm{E}$ diets was grass silage.

Postcalving, animals managed on the high $\mathrm{E}$ and low E precalving treatments were offered ad libitum access to either a high (high E) or low (low E) energy lactation diet and remained on these diets until d 250 of lactation. The $\mathrm{F}: \mathrm{C}$ ratios of the high $\mathrm{E}$ and low $\mathrm{E}$ postcalving diets were 30:70 and 70:30, respectively (DM basis), providing 12.5 and $11.7 \mathrm{MJ}$ of $\mathrm{ME} / \mathrm{kg}$ of
DM, respectively. The forage component of the postcalving diet consisted of grass silage and maize silage (1:1 ratio, DM basis). Concentrate composition and analysis is presented in Table 1. The energy and protein concentrations of individual ingredients were based on published values (AFRC, 1993).

Primiparous animals were assigned to postcalving treatment according to precalving treatment, calving date, and BCS and BW at d 21 precalving. Multiparous animals were assigned to postcalving treatment according to precalving treatment, parity, previous 305-d milk yield, calving date, and BCS and BW at d 21 precalving. Consequently, there were 4 treatments groups: high E precalving, high E postcalving $(\mathbf{H H})$; high E precalving, low E postcalving (HL); low E precalving, high E postcalving (LH); low E precalving, low E postcalving $(\mathbf{L L})$. The CP contents of pre- and postcalving diets were maintained at 170 and $190 \mathrm{~g} / \mathrm{kg}$ of DM respectively. Animals on the low E postcalving diet received an additional $50 \mathrm{~g} / \mathrm{d}$ of a mineral preparation to ensure that total mineral intakes were similar on both treatments. Diets were prepared daily in a mixer wagon and offered as a TMR between 1000 and $1100 \mathrm{~h}$ via feed boxes placed on a series of computerlinked load cells. Access to feed boxes was controlled by an electronic identification system (described previously), enabling fresh intakes of individual animals to be recorded continuously. Dry matter intakes were then calculated using daily oven DM values for grass and maize silage and fortnightly oven DM values for concentrates, as detailed below. Daily intakes were used 
Table 2. Chemical composition of grass silage and maize silage as offered throughout the experiment

\begin{tabular}{|c|c|c|c|c|c|}
\hline \multirow[b]{2}{*}{ Analysis } & \multicolumn{3}{|c|}{ Grass silage $^{1}$} & \multicolumn{2}{|c|}{ Maize silage } \\
\hline & $\begin{array}{c}\text { Late } \\
\text { lactation }\end{array}$ & $\begin{array}{c}\text { Dry } \\
\text { period }\end{array}$ & Postcalving & $\begin{array}{c}\text { Late } \\
\text { lactation }\end{array}$ & Postcalving \\
\hline Oven DM (g/kg) & 170 & 198 & 228 & 297 & 289 \\
\hline $\operatorname{VCODM}^{2}(\mathrm{~g} / \mathrm{kg})$ & 185 & 215 & 248 & 311 & 302 \\
\hline $\mathrm{pH}$ & 3.12 & 3.59 & 3.99 & 3.56 & 3.68 \\
\hline \multicolumn{6}{|l|}{ Composition of DM (g/kg of DM) } \\
\hline $\mathrm{CP}$ & 136 & 141 & 147 & 78 & 86 \\
\hline Ammonia nitrogen $(\mathrm{g} / \mathrm{kg}$ of $\mathrm{N})$ & 125 & 129 & 101 & 91 & 96 \\
\hline Ethanol & 3.7 & 3.7 & 4.5 & - & - \\
\hline Propanol & 0.8 & 0.9 & 0.6 & - & - \\
\hline Lactic acid & 17 & 17 & 21 & - & - \\
\hline Acetic acid & 6.4 & 6.1 & 5.2 & - & - \\
\hline Propionic acid & 0.5 & 0.4 & 0.6 & - & - \\
\hline n-Butyric acid & 1.7 & 1.2 & 1.0 & - & - \\
\hline $\mathrm{ADF}$ & 320 & 325 & 315 & 275 & 288 \\
\hline $\mathrm{NDF}$ & 564 & 565 & 536 & 528 & 552 \\
\hline Ash & 72 & 75 & 82 & 37 & 38 \\
\hline Starch & - & - & - & 219 & 200 \\
\hline Gross energy (MJ/kg of DM) & 17.1 & 16.9 & 18.7 & 18.1 & 18.2 \\
\hline $\mathrm{ME}^{3}(\mathrm{MJ} / \mathrm{kg}$ of $\mathrm{DM})$ & 10.3 & 10.3 & 11.4 & 11.1 & 10.6 \\
\hline
\end{tabular}

${ }^{1}$ During late lactation and the dry period, grass silages were produced from primary regrowth herbage. Postcalving, grass silage was produced from predominantly primary growth herbage.

${ }^{2} \mathrm{VCODM}=$ volatile-corrected oven DM.

${ }^{3}$ Determined by near infrared reflectance spectroscopy (Park et al., 1998).

to calculate an average daily intake for each week of lactation. Postcalving, diet allocation included a target excess of $7 \%$ daily and uneaten material was removed thrice weekly.

\section{Measurements (Diets)}

Daily samples were analyzed for oven DM (Table 2), and weekly samples of grass silage and maize silage were analyzed by near infrared reflectance spectroscopy to estimate ME content (Park et al., 1998). Twice weekly, fresh samples of maize silage and grass silage were analyzed for gross energy (Porter, 1992) and pH. The same samples were analyzed for $\mathrm{N}$ and ammonia- $\mathrm{N}$ concentrations as described by Steen (1989), and for lactic acid, VFA, ethanol, and propanol concentrations as described by Porter and Murray (2001). Four dried silage samples (2 per week) were bulked for each 2 -wk period and analyzed for concentrations of NDF, ADF, and ash as described by Cushnahan and Gordon (1995). Twice weekly, samples of maize silage were dried at $60^{\circ} \mathrm{C}$, bulked for each 2 -wk period, and analyzed for starch according to McCleary et al. (1994) using a commercial kit (Megazyme, Megazyme International Ireland Ltd., Bray, Ireland). Each batch of concentrates produced was sampled and bulked 2-wk samples were analyzed for oven DM content. The dried samples were analyzed for nitrogen (Steen, 1989), ADF, NDF, and ash concentrations as described by Cushnahan and
Gordon (1995). A separate concentrate sample was dried at $60^{\circ} \mathrm{C}$ and similarly bulked and analyzed for starch as detailed above (Table 1). Volatility coefficients (Porter and Murray, 2001) were used with the oven DM contents of the grass silage and maize silage to produce volatile-corrected oven DM (VCODM) values.

\section{Measurements (Animals)}

Cows were milked twice daily, between 0530 and 0700 $\mathrm{h}$, and between 1530 and $1700 \mathrm{~h}$, through a 50-point rotary parlor. Milk yield was recorded automatically at each milking for each individual animal, and a mean daily milk yield was calculated for each animal on a weekly basis. Milk samples were taken for fat, protein, lactose, and SCC analysis weekly from 2 consecutive collections (a.m. and p.m.) from each animal, with a.m. and p.m. samples analyzed separately using an infrared milk analyzer. Each sample had a preservative tablet added (Lactab Mark III, Thompson and Cooper Ltd., Runcorn, UK) and was stored at $4^{\circ} \mathrm{C}$ until analyzed. A weighted milk composition was subsequently calculated for each weekly sampling occasion. Body condition score on a scale from 1 to 5 (Edmonson et al., 1989) and BW were measured weekly from $\mathrm{d}-42(-21$ in primiparous animals) until the end of the study.

Liver biopsies of approximately $20 \mathrm{mg}$ wet weight (each) were taken from 4 primiparous and 4 multiparous animals on each of the 4 treatments, at $13 \mathrm{~d}$ before 
their expected calving dates and at 10,22, and $56 \mathrm{~d}$ postcalving. Samples were obtained through a small incision on the right hand side of the animal between the 10th and 11th ribs, on a line from the hip (tuber coxae) to the upper part of the right front leg (mid-humerus). Before taking the biopsies, a $25-\mathrm{cm}^{2}$ area of the skin was shaved and disinfected and $10 \mathrm{~mL}$ of local anesthetic administered subdermally. Following a minimum wait of $10 \mathrm{~min}$, a $0.5-\mathrm{cm}$ incision was made in the skin. Liver biopsies were taken from this incision using a Pro-Mag biopsy tool with a 14 gauge $\times 10$-cm needle $(\mathrm{MDTEH}$, FL, Gainesville, FL). The biopsies were immediately frozen in liquid nitrogen and stored at $-180^{\circ} \mathrm{C}$ until analysis for triacylglycerol (TAG) content. Before analysis, liver samples were homogenized and centrifuged, and supernatants were analyzed on an auto analyzer using colorimetric kits (Andersen et al., 2002).

From $-21 \mathrm{~d}$ precalving until d 100 of lactation, all animals were blood sampled weekly before being offered fresh food. Blood was taken from the coccygeal vein into uncoated, heparin-coated, and fluoride oxalate-coated tubes (BD, Oxford, UK). Plasma was recovered by centrifugation from fluoride oxalate tubes for analysis of glucose and NEFA, and from heparinized tubes for analysis of total protein, albumin, urea, and BHBA. All analyses were carried out on a clinical analyzer (AU640, Olympus UK Ltd., Middlesex, UK). Plasma concentrations of total protein, albumin, glucose, and urea were determined using Olympus kits (Olympus Life Science Research Europa, Munich, Germany). Reagents for total protein, albumin, glucose, and urea were ready for use and placed appropriately into the analyzer. In the analysis of total protein, cupric ions in an alkaline solution react with proteins and polypeptides containing at least 2 peptide bonds to produce a violet complex. The absorbance of the complex at $540 / 660 \mathrm{~nm}$ is directly proportional to the concentration of protein in the sample (Young, 2000). For albumin, a colored complex is formed when bromocresol green (BCG) reacts with albumin. The absorbance of the albumin-BCG complex is measured bichromatically $(600 / 800 \mathrm{~nm})$ and is proportional to the concentration of albumin in the sample (Young, 2000). Glucose is phosphorylated by hexokinase in the presence of ATP and $\mathrm{Mg}^{2+}$ to produce glucose-6-phosphate and ADP. Glucose-6-phosphate dehydrogenase specifically oxidizes glucose-6-phosphate to gluconate-6-phosphate with the concurrent reduction of $\mathrm{NAD}^{+}$to NADH. The increase in absorbance at $340 \mathrm{~nm}$ is proportional to the glucose concentration in the sample (Young, 2000). Urea is hydrolyzed in the presence of water and urease to produce ammonia and carbon dioxide. The ammonia produced in the first reaction combines with 2-oxoglutarate and $\mathrm{NADH}$ in the presence of glutamate-dehydrogenase to yield glutamate and $\mathrm{NAD}^{+}$. The decrease in $\mathrm{NADH}$ absorbance per unit time is proportional to the concentration of urea (Young, 2000). Concentrations of NEFA were determined using a standard Wako reagent kit NEFA-HR(2) (Wako Chemicals GmbH, Neuss, Germany). Reagants were prepared according to Krebs et al. (2000). Nonesterified fatty acids are converted to acylCoA, AMP, and pyrophosphoric acid by the action of acyl-CoA synthetase, under coexistence with coenzyme $\mathrm{A}$ and adenosine 5-triphosphate disodium salt. Obtained acyl-CoA is oxidized and yields 2,3-trans-enoyl$\mathrm{CoA}$ and hydrogen peroxide by the action of acyl-CoA oxidase. In the presence of peroxidase, the hydrogen peroxide formed yields a blue-purple pigment by quantitative oxidation condensation with 3-methyl-N-ethyl$\mathrm{N}$-( $\beta$-hydroxyethyl)-aniline and 4-aminoantipyrine. The concentration of NEFA is obtained by measuring absorbance of the blue purple color. The concentration of BHBA in plasma was determined according to McMurray et al. (1984).

Serum was recovered by centrifugation of uncoated tubes for analysis of leptin and IGF-1. Leptin concentrations were determined by RIA of samples from all animals in each of wk $-3,-2,-1,2,5,8$, and 12 postpartum. The leptin RIA was performed according to Wylie et al. (2008) and used bovine leptin (a gift from A. Gertler, Protein Laboratories, Rehovot, Israel and, formerly, The Hebrew University of Jerusalem, Israel) as both standard and as iodinated label. Each assay was balanced for dietary treatment and for parity and control samples were included in each assay. Serum IGF-1 concentrations were also determined by RIA in samples from wk 2, 5, 8, 16, and 20 from the same 7 multiparous and 5 primiparous animals randomly selected from each of the 4 dietary treatments. The IGF-1 RIA were balanced for dietary treatment and parity, with control samples included in each assay; IGF-1 binding proteins were removed by acid-ethanol cryoprecipitation (Wylie et al., 1997) before analysis. The primary antibody (AFP 4892898) was rabbit anti-human somatomedin C (a gift from A. Parlow; NIDDK, Torrance, CA) and was used at a final dilution of 1:400,000.

\section{Calculation of Energy Balance}

The average daily energy balance (DEB) for each animal was calculated for each week of lactation using the equations described by Thomas (2004): $\mathrm{DEB}=\mathrm{ME}$ intake $-\mathrm{ME}$ requirement $\left[-10+\left(\mathrm{ME}_{\text {preg }}+\mathrm{ME}_{\text {maintmilk }}\right.\right.$ $\left.\left.\times \mathrm{BW}^{0.75}\right)\right]+\left[(0.0013 \times \mathrm{BW}) / \mathrm{K}_{\mathrm{m}}\right] ; \mathrm{K}_{\mathrm{m}}=$ efficiency of energy use for maintenance $(0.35 \times \mathrm{ME} /$ gross energy + 0.503). Milk yields, DMI, milk compositions, BW, and feed composition data were all used in the calculations. Missing values ( $<2 \%$ of all values) were estimated from 
Table 3. Composition of TMR as fed, indicating DM, CP, and ME contents ${ }^{1}$

\begin{tabular}{|c|c|c|c|c|c|c|c|c|c|c|c|c|}
\hline Item & \multicolumn{2}{|c|}{ High precalving } & \multicolumn{3}{|c|}{ Low precalving } & \multicolumn{3}{|c|}{ High postcalving } & \multicolumn{4}{|c|}{ Low postcalving } \\
\hline DM content $(\mathrm{g} / \mathrm{kg})$ & 870 & 198 & 870 & 870 & 198 & 870 & 228 & 289 & 870 & 870 & 228 & 289 \\
\hline $\mathrm{CP}(\mathrm{g} / \mathrm{kg}$ of $\mathrm{DM})$ & 220 & 141 & 220 & 540 & 141 & 220 & 147 & 86 & 220 & 540 & 147 & 86 \\
\hline $\mathrm{ME}(\mathrm{MJ} / \mathrm{kg}$ of $\mathrm{DM})$ & 13.1 & 10.3 & 13.1 & 13.4 & 10.3 & 13.1 & 11.4 & 10.6 & 13.1 & 13.4 & 11.4 & 10.6 \\
\hline Starch $(\mathrm{g} / \mathrm{kg}$ of $\mathrm{DM})$ & \multicolumn{2}{|c|}{$\begin{array}{r}169 \\
79\end{array}$} & \multicolumn{3}{|c|}{29} & \multicolumn{3}{|c|}{183} & \multicolumn{4}{|c|}{113} \\
\hline
\end{tabular}

${ }^{1}$ Precalving diet denotes the dry period of multiparous animals and $3 \mathrm{wk}$ before calving in primiparous animals; animals on the low postcalving diet received an additional $50 \mathrm{~g}$ of dairy cow mineral/head per day. High and low refer to energy content.

${ }^{2}$ Conc. $=$ concentrate.

data for the week before and the week following the week in which observations were missing.

\section{Statistical Analysis}

Data were analyzed by a repeated measures approach using the REML procedure in GenStat (Payne et al., 2007). Pre- and postcalving data were analyzed separately. Within each of these data sets, data from primi- and multiparous animals were also considered separately. For precalving data, the model fitted fixed effects for precalving treatment and weeks before calving for each parameter. For postcalving data, the model fitted fixed effects for precalving treatment, postcalving treatment, and week of lactation for each parameter. The model included all 2-way and 3-way interactions among these variables. Linear regression analysis was undertaken for several independent variables relating to energy and liver metabolism. These were BCS, DEB, cumulative energy balance (CEB), and concentrations of plasma NEFA and BHBA, serum leptin and IGF-1, and liver TAG.

\section{RESULTS}

\section{Chemical Composition of the Silages and Concentrates}

The chemical composition of concentrates offered during late lactation, the dry period, and lactation are presented in Table 1. Concentrates had similar ME, $\mathrm{NDF}, \mathrm{ADF}$, and ash contents but differed in $\mathrm{CP}$ and starch contents. The chemical composition of silages (DM basis) is presented in Table 2. The grass silage offered postcalving was considered to be of good quality with a DM content of $228 \mathrm{~g} / \mathrm{kg}$ of DM, a CP concentration of $147 \mathrm{~g} / \mathrm{kg}$ of $\mathrm{DM}$, and an ammonia-N concentration of $101 \mathrm{~g} / \mathrm{kg}$ of total $\mathrm{N}$ (consistent with good preservation). The maize silage offered postcalving had a DM content of $289 \mathrm{~g} / \mathrm{kg}$, a CP concentration of 86 $\mathrm{g} / \mathrm{kg}$ of DM, and a starch concentration of $200 \mathrm{~g} / \mathrm{kg}$ of DM, typical of average quality maize forage. Table 3 details the mean composition of the various rations offered (DM basis).

\section{Effect of Precalving Diet on BCS, DMI, and Energy Indices in the Precalving Period (-21 to $0 \mathrm{~d}$ )}

During the precalving period, primiparous animals offered the low $\mathrm{E}$ diet had lower leptin concentrations $(P=0.046)$ and mean BCS $(P=0.03)$ than those offered the high $\mathrm{E}$ diet (Table 4). Primiparous animals offered the low $\mathrm{E}$ diet also had higher $(P<0.001)$ plasma urea concentrations than animals offered the high E diet (Table 4), but no precalving dietary effects $(P>0.05)$ were observed for DMI, BCS at calving, BCS change, BW, DEB, or for plasma NEFA, glucose, or BHBA concentrations (Table 4).

Multiparous animals offered the high $\mathrm{E}$ diet during the precalving period had higher DMI $(P<0.001)$, BCS $(P=0.04)$, BCS at calving $(P=0.007)$, DEB $(P<0.001)$, and plasma glucose concentrations $(P<$ 0.001) compared with those offered a low E diet (Table 4). Multiparous animals offered a low E precalving diet had higher plasma urea concentrations $(P=0.044)$ and lost more body condition $(P=0.015)$ than animals offered a high E precalving diet (Table 4$)$. No $(P>0.05)$ precalving dietary effects on plasma NEFA or BHBA concentrations or serum leptin concentrations (Table 4) were observed in multiparous animals.

Regression analysis of data from multiparous animals revealed a strong positive association between BCS at drying off and BCS at calving $\left(P<0.001 ; \mathrm{r}^{2}=\right.$ $0.63)$. Precalving treatment had a significant effect on the intercept $\left(P=0.01 ; \mathrm{r}^{2}=0.054\right)$ and trajectory $(P$ $\left.=0.022 ; \mathrm{r}^{2}=0.042\right)$ of this relationship. The fitted 
Table 4. Effect of precalving diet on mean DMI, BCS, BW, energy status, and blood metabolite concentrations during the precalving period $(-21$ to $0 \mathrm{~d})$

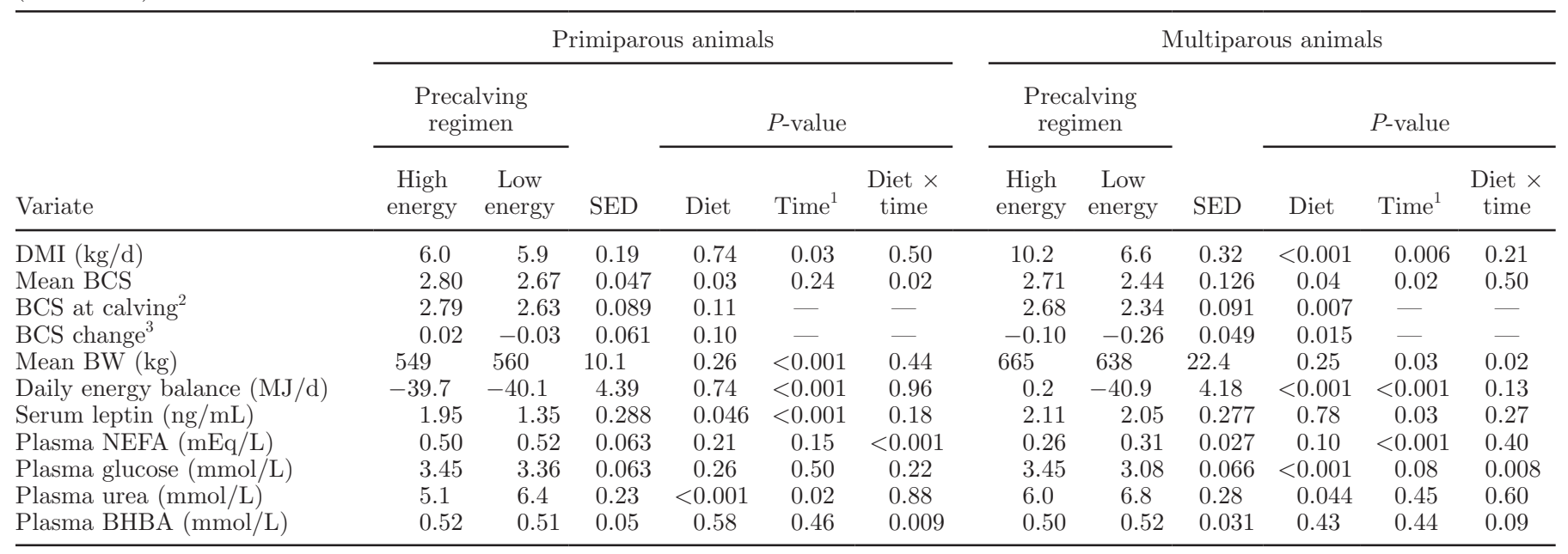

${ }^{1}$ Time $=$ week precalving.

${ }^{2} \mathrm{BCS}$ at calving was calculated as an average of BCS in wk -1 and +1 postcalving.

${ }^{3} \mathrm{BCS}$ change (total change) from -42 to $0 \mathrm{~d}$ precalving for multiparous animals and from -21 to $0 \mathrm{~d}$ precalving for primiparous animals.

equation for this relationship was $\mathrm{Y}=1.295-1.119$ (precalving treatment, low $\mathrm{E})+0.477(\mathrm{X})+0.356(\mathrm{X}$; precalving treatment, low $\mathrm{E}$ ).

\section{Effect of Precalving and Postcalving Diet on Energy and Production Parameters (1 to 250 d)}

Primiparous Animals. During the postcalving period (1-250 d), primiparous animals offered a low
E diet precalving were significantly heavier (519 vs. $478 \mathrm{~kg} / \mathrm{d} ;$ SED $=12.5 ; P=0.001)$ than primiparous animals offered a high $\mathrm{E}$ diet precalving (Table 5). Diet identity precalving had no direct effect $(P>0.05)$ on BCS, ME requirement, ME intake (Table 5; Figure 1), DMI, DEB, CEB, milk energy output, yields of milk, milk fat, protein, fat plus protein, or lactose, nor on concentrations of milk fat, protein, or lactose (Tables 5 and 6$)$.

Table 5. Effect of pre- and postcalving diets on mean BW, BCS, and body energy status of multiparous animals from d 1 to 250 of lactation

\begin{tabular}{|c|c|c|c|c|c|c|c|c|c|c|c|}
\hline Item & \multicolumn{4}{|c|}{$\begin{array}{c}\text { Dietary regimen } \\
{\text { (precalving/postcalving })^{1}}^{1}\end{array}$} & SED & \multicolumn{6}{|c|}{$P$-value } \\
\hline \multicolumn{12}{|l|}{ Primiparous } \\
\hline $\mathrm{BW}(\mathrm{kg})$ & 480 & 476 & 536 & 502 & 17.7 & 0.001 & 0.15 & $<0.001$ & 0.24 & $<0.001$ & $<0.001$ \\
\hline BCS & 2.49 & 2.49 & 2.60 & 2.53 & 0.074 & 0.12 & 0.56 & $<0.001$ & 0.58 & $<0.001$ & $<0.001$ \\
\hline Daily energy status $(\mathrm{MJ} / \mathrm{d})$ & 4.7 & -15.3 & 20.3 & -23.2 & 7.37 & 0.17 & $<0.001$ & $<0.001$ & 0.03 & $<0.001$ & 0.22 \\
\hline Cumulative energy status (MJ) & -665 & $-2,915$ & 2,119 & $-3,676$ & 958 & 0.06 & $<0.001$ & $<0.001$ & 0.01 & 0.02 & $<0.001$ \\
\hline \multicolumn{12}{|l|}{ Multiparous } \\
\hline BW (kg) & 607 & 575 & 603 & 580 & 24.4 & 0.95 & 0.12 & $<0.001$ & 0.80 & $<0.001$ & 0.009 \\
\hline $\mathrm{BCS}$ & 2.78 & 2.29 & 2.65 & 2.38 & 0.145 & 0.54 & 0.002 & $<0.001$ & 0.14 & 0.005 & $<0.001$ \\
\hline ME requirement $(\mathrm{MJ} / \mathrm{d})$ & 236 & 210 & 230 & 217 & 10.5 & 0.87 & 0.01 & $<0.001$ & 0.36 & 0.02 & 0.005 \\
\hline ME intake $(\mathrm{MJ} / \mathrm{d})$ & 252 & 203 & 262 & 189 & 10.6 & 0.99 & $<0.001$ & $<0.001$ & 0.114 & 0.65 & $<0.001$ \\
\hline
\end{tabular}

${ }^{1} \mathrm{HH}=$ high energy (E) precalving, high E postcalving; HL = high E precalving, low E postcalving; LH = low E precalving, high E postcalving; $\mathrm{LL}=$ low E precalving, low E postcalving.

${ }^{2}$ Interactions 1,2 , and $3=$ pre- $\times$ postcalving treatment, precalving treatment $\times$ week of lactation, and postcalving treatment $\times$ week of lactation, respectively.

${ }^{3}$ Time $=$ week of lactation. 


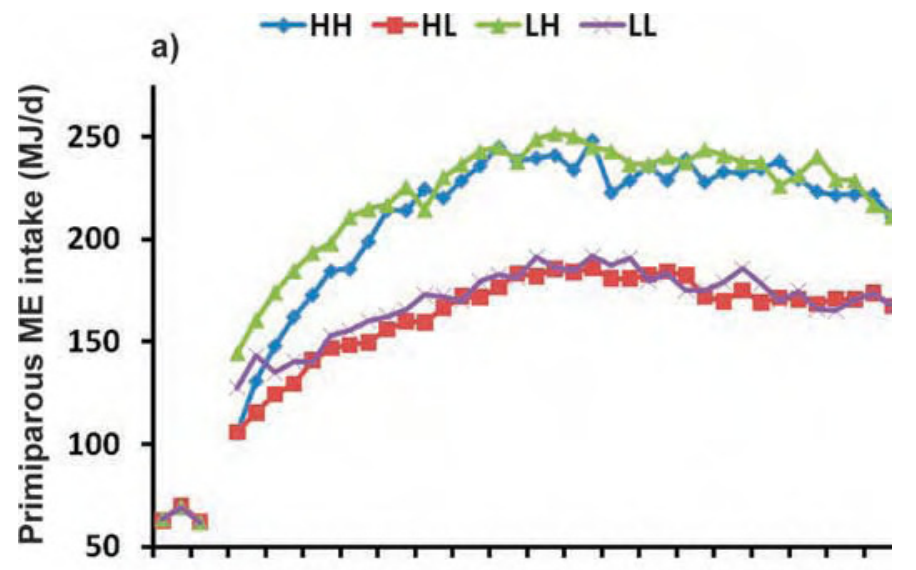

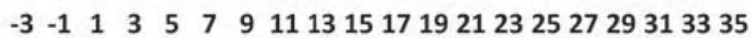

Week of lactation

b)

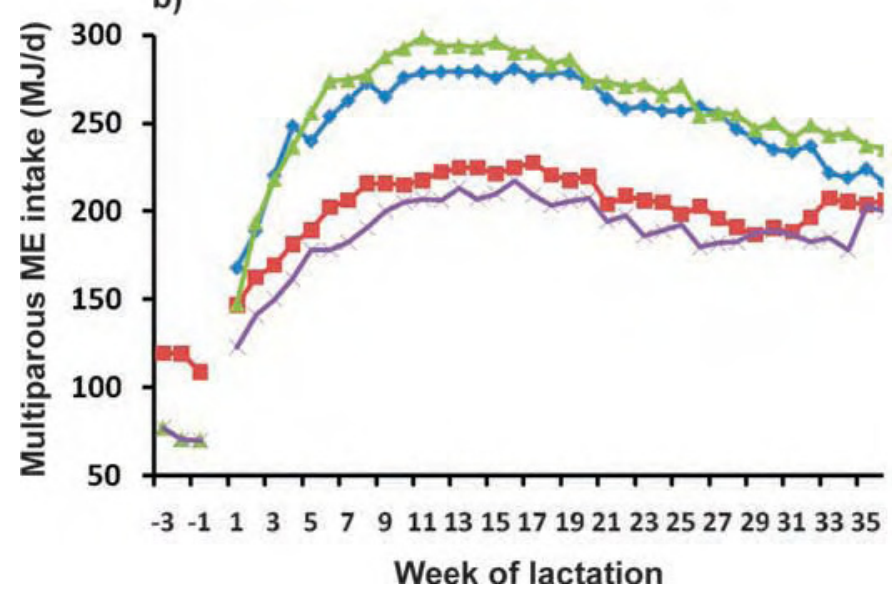

Figure 1. Metabolizable energy intake of animals offered 2 levels of energy intake (high and low), pre- and postcalving: $\mathrm{HH}=$ high energy (E) precalving, high E postcalving; $\mathrm{HL}=$ high $\mathrm{E}$ precalving, low $\mathrm{E}$ postcalving; $\mathrm{LH}=$ low E precalving, high E postcalving; LL = low E precalving, low E postcalving. Postcalving effects in primiparous animals: precalving treatment, $P=0.06$ (SED, 5.1); postcalving treatment, $P<0.001$ (SED, 5.1); week of lactation $\times$ precalving treatment $\times$ postcalving treatment, $P=0.93$ (SED, 10.4). Postcalving effects in multiparous animals: precalving treatment, $P=0.99$ (SED, 7.5); postcalving treatment, $P<0.001$ (SED, 7.5); week of lactation $\times$ precalving treatment $\times$ postcalving treatment, $P=0.98(\mathrm{SED}, 13.6)$. Color version available in the online PDF.

Primiparous animals receiving a high E postcalving diet had higher ME requirement (207 vs. $187 \mathrm{MJ} / \mathrm{d}$; $\mathrm{SED}=5.9 ; P=0.01)$, ME intakes $(219$ vs. $167 \mathrm{MJ} / \mathrm{d}$; $\mathrm{SED}=5.1 ; P<0.001)$, DMI $(17.8$ vs. $14.5 \mathrm{~kg} / \mathrm{d} ;$ SED $=0.43 ; P<0.001)$, milk yields $(29.7$ vs. $24.8 \mathrm{~kg} / \mathrm{d} ; \mathrm{SED}$ $=1.27 ; P<0.001)$ milk protein yields $(0.99$ vs. 0.81 $\mathrm{kg} / \mathrm{d} ; \mathrm{SED}=0.037 ; P<0.001)$, milk fat plus protein yields $(2.07$ vs. $1.84 \mathrm{~kg} / \mathrm{d} ; \mathrm{SED}=0.079 ; P=0.005)$, milk energy outputs (89.5 vs. $79.3 \mathrm{MJ} / \mathrm{d} ; \mathrm{SE}=3.42 ; P$ $=0.03)$, DEB (12.5 vs. $-19.2 \mathrm{MJ} / \mathrm{d} ; \mathrm{SED}=5.2 ; P<$
0.001), and CEB (727 vs. $-3,296 \mathrm{MJ} ; \mathrm{SED}=678 ; P<$ $0.001)$ compared with animals receiving the low E postcalving diet (Tables 5 and 6). Animals offered a low E postcalving diet had higher milk fat concentration (41.7 vs. $37.0 \mathrm{~g} / \mathrm{kg}$; SED $=1.47 ; P=0.003)$ than animals offered the high E postcalving diet (Table 6). Postcalving diet did not affect $(P>0.05)$ BW, BCS, milk fat yield, or concentrations of milk protein and lactose.

In primiparous animals, a precalving $\times$ postcalving diet interaction was found for DEB $(P=0.03)$, CEB $(P$ $=0.01)$, and milk fat yield $(P=0.02)$. For both DEB and $\mathrm{CEB}$, the magnitude, but not the direction, of the energy-related response to postcalving treatment was influenced by precalving treatment (Table 5) such that differences in DEB and CEB between the postcalving treatments were greater in animals offered a low $\mathrm{E}$ diet precalving than in those offered a high $\mathrm{E}$ diet precalving. With regard to milk fat yield, animals offered a high $\mathrm{E}$ diet precalving had a higher milk fat yield when offered a high E diet postcalving compared with those offered a low E diet postcalving. However, when offered a low E diet precalving, animals offered the low E diet postcalving had higher milk fat yield compared with those offered a high E diet postcalving (Table 6).

Significant 3 -way interactions (week of lactation $\times$ precalving treatment $\times$ postcalving treatment) were found for milk yield $(P<0.001$; SED $=1.59$; Figure 2$)$, milk lactose yield $(P<0.001)$, BCS $(P<0.001)$, BW $(P=0.012)$, total energy requirement $(P=0.005)$, and $\mathrm{CEB}(P<0.001$; SED $=979$; Figure 3$)$. For all of these parameters, the precalving treatment significantly affected the postcalving response trajectory.

Multiparous Animals. For multiparous animals, no significant $(P>0.05)$ effects of precalving treatment were observed on any of the parameters listed in Tables 5 and 6 . During the first $250 \mathrm{~d}$ of lactation, multiparous animals offered a high $\mathrm{E}$ diet postcalving had a higher BCS (2.67 vs. 2.33; SED $=0.10 ; P=0.002)$, ME requirement (233 vs. $214 \mathrm{MJ} / \mathrm{d} ; \mathrm{SED}=7.5 ; P=0.01$ ), ME intake (257 vs. $196 \mathrm{MJ} / \mathrm{d}$; SED $=7.5 ; P<0.001$ ), DMI (20.9 vs. $17.0 \mathrm{~kg} / \mathrm{d}$; SED $=0.62 ; P<0.001)$, milk yield (33.5 vs. $28.2 \mathrm{~kg} / \mathrm{d}$; SED $=1.49 ; P<0.001)$, milk protein yield $(1.09$ vs. $0.95 \mathrm{~kg} / \mathrm{d}$; SED $=0.041 ; P<$ $0.001)$, milk energy output (99.5 vs. $90.0 \mathrm{MJ} / \mathrm{d}$; SED $=4.14 ; P=0.02)$, DEB $(24.0$ vs. $-17.2 \mathrm{MJ} / \mathrm{d} ; \mathrm{SED}=$ 7.40; $P<0.001)$, and CEB (2,443 vs. $-3,471 \mathrm{MJ}$; SED $=974 ; P<0.001)$ than those offered the low $\mathrm{E}$ postcalving diet (Tables 5 and 6). Animals offered the low E postcalving diet had higher milk fat concentrations (36.8 vs. $42.0 ; \mathrm{SED}=1.94 ; P=0.009$ ) than animals offered the high E postcalving diet (Table 6).

In multiparous animals, a precalving $\times$ postcalving diet interaction was found for DEB $(P=0.02)$ with the magnitude, but not the direction, of the energy- 
Table 6. Effect of pre- and postcalving diets on mean DMI, milk yield, milk constituent variables, and milk energy from 1 to 250 d of lactation

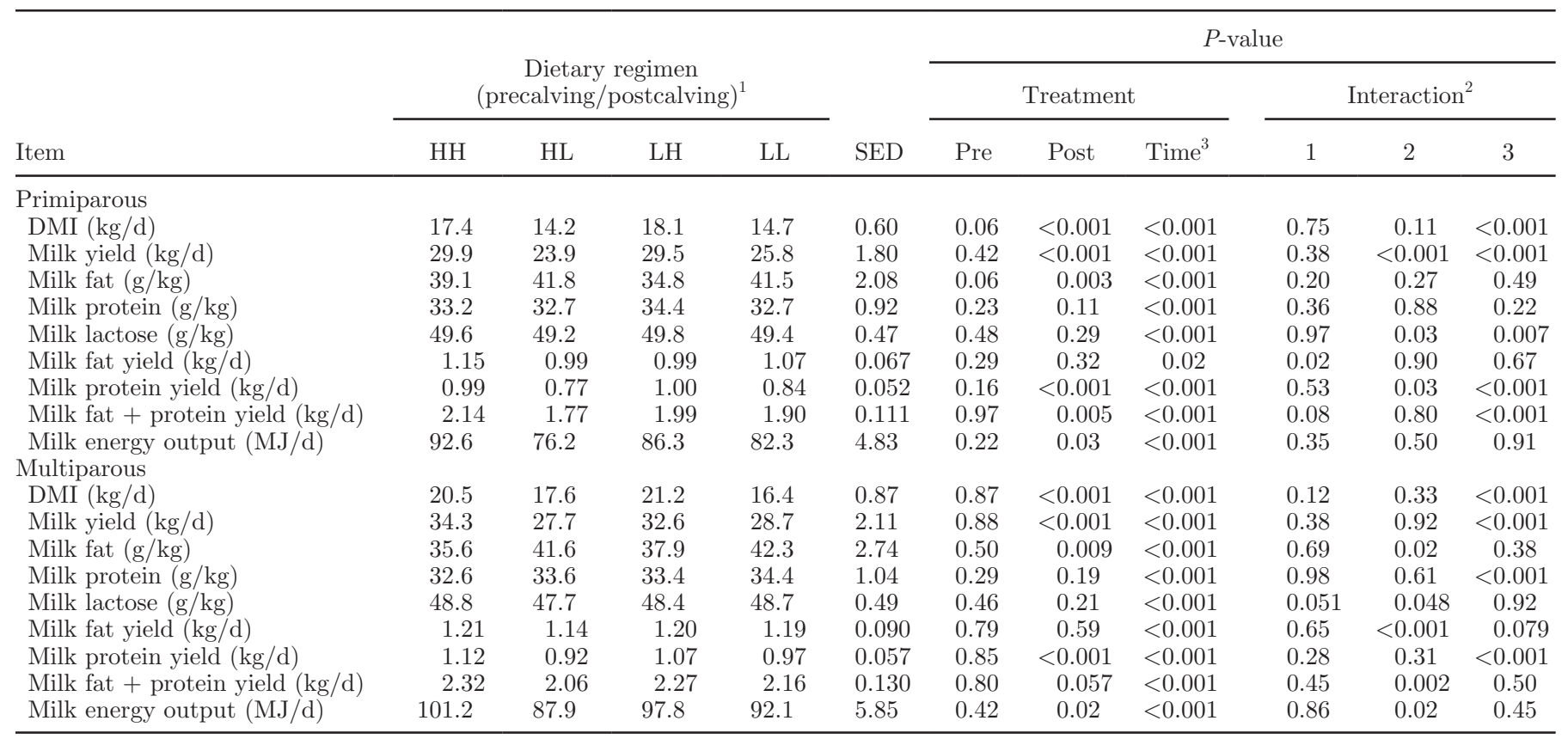

${ }^{1} \mathrm{HH}=$ high energy (E) precalving, high E postcalving; $\mathrm{HL}=$ high E precalving, low E postcalving; LH = low E precalving, high E postcalving; $\mathrm{LL}=$ low $\mathrm{E}$ precalving, low E postcalving.

${ }^{2}$ Interactions 1,2 , and $3=$ pre- $\times$ postcalving treatment, precalving treatment $\times$ week of lactation, and postcalving treatment $\times$ week of lactation, respectively.

${ }^{3}$ Time $=$ week of lactation.

related response to postcalving treatment influenced by precalving treatment (Table 5). The difference between high $\mathrm{E}$ and low $\mathrm{E}$ postcalving treatments was greater in animals receiving the low $\mathrm{E}$ diet precalving than in those receiving the high $\mathrm{E}$ diet precalving.

Three-way interactions $(P<0.001$; week of lactation $\times$ precalving treatment $\times$ postcalving treatment) were found for milk yield (Figure 2; SED = 1.59), milk fat yield, milk protein yield, milk fat plus protein yield, total energy requirement, DEB (Figure 4; SED = 14.1), and CEB (Figure 3; SED = 979). For all of these parameters, precalving treatment significantly affected on the postcalving response trajectory.

\section{Effect of Precalving and Postcalving Diets on Blood and Liver Parameters (1 to 100 d)}

Primiparous Animals. Precalving diet had a significant effect on postcalving plasma NEFA (Table 7; Figure 5) and BHBA concentrations (Table 7), with those managed on high $\mathrm{E}$ and low $\mathrm{E}$ precalving diets having mean NEFA concentrations of 0.44 and 0.39 $\mathrm{mEq} / \mathrm{L}(\mathrm{SED}=0.023 ; P=0.006)$ and BHBA concentrations of 0.55 and $0.49 \mathrm{mmol} / \mathrm{L}(\mathrm{SED}=0.025 ; P=$ $0.003)$ respectively, during the postcalving period. No significant effects $(P>0.05)$ of precalving treatment on plasma glucose or urea concentrations, on serum IGF-1 or leptin concentrations, or on liver TAG concentrations were found.

Primiparous animals offered a high E postcalving diet had higher serum IGF-1 concentrations $(P<0.001 ; 115$ vs. $99 \mathrm{ng} / \mathrm{mL}, \mathrm{SED}=7.3)$ than those offered a low $\mathrm{E}$ diet postcalving. Animals offered a high E diet postcalving had lower concentrations of plasma urea (5.1 vs. $6.5 \mathrm{mmol} / \mathrm{L} ; \mathrm{SED}=0.16 ; P<0.001)$ and BHBA $(0.44$ vs. $0.60 \mathrm{mmol} / \mathrm{L} ; \mathrm{SED}=0.025 ; P<0.001)$ compared with those offered a low $\mathrm{E}$ diet postcalving. No significant $(P>0.05)$ effect of postcalving dietary regimen on plasma NEFA or glucose concentrations, on serum leptin concentrations, or on liver TAG concentrations during lactation was found (Table 7).

Multiparous Animals. Among multiparous animals, precalving diet had no effect $(P>0.05)$ on blood or liver parameters during the postcalving period (Table 7). Multiparous animals offered a high E postcalving diet had higher plasma glucose concentrations (3.5 vs. $3.3 \mathrm{mmol} / \mathrm{L}, \mathrm{SED}=0.04 ; P<0.001)$ than those offered the low $\mathrm{E}$ diet postcalving. Animals offered a high $\mathrm{E}$ postcalving diet had lower plasma concentrations of urea $(5.5$ vs. $7.0 \mathrm{mmol} / \mathrm{L} ; \mathrm{SED}=0.14 ; P<0.001)$, BHBA 
$(0.46$ vs. $0.57 \mathrm{mmol} / \mathrm{L} ; \mathrm{SED}=0.030 ; P=0.002)$, and NEFA (0.31 vs. $0.39 \mathrm{mEq} / \mathrm{L} ; \mathrm{SED}=0.032 ; P=0.02)$ compared with those offered the low E diet postcalving. In these multiparous animals, no effect $(P>0.05)$ of postcalving dietary regimen on serum leptin or IGF-1 concentrations or on liver TAG concentrations during lactation was observed (Table 7).

Regression analysis of all data (primiparous and multiparous animals) showed that a more negative DEB was associated with increased plasma NEFA $\left(\mathrm{r}^{2}=\right.$ 0.284; $P<0.001)$ and liver TAG $\left(\mathrm{r}^{2}=0.325 ; P<0.001\right)$ concentrations. Postcalving treatment had a significant effect on the intercept in both regressions (NEFA, $\mathrm{r}^{2}=$ $0.07, P=0.005$; TAG, $\left.\mathrm{r}^{2}=0.05, P<0.02\right)$. The fitted equation for NEFA was $\mathrm{Y}=0.451-0.201$ (postcalving treatment, low E) - $0.00477(\mathrm{X})$, whereas that for TAG was $\mathrm{Y}=4.523-3.07$ (postcalving treatment, low $\mathrm{E}$ ) 0.0866 (X). Additionally, plasma NEFA concentrations were positively associated with liver TAG concentrations $\left(\mathrm{r}^{2}=0.319 ; P<0.001\right)$ and postcalving treatment did not affect this regression $(P=0.19)$. Thus, the fitted equation for TAG was $\mathrm{Y}=1.02+9.83(\mathrm{X})$.

Additional regression analysis indicated that a more negative DEB was associated with increased plasma BHBA $\left(\mathrm{r}^{2}=0.097 ; P<0.001\right)$, whereas a more negative CEB was associated with lower serum IGF-1 concentrations $\left(\mathrm{r}^{2}=0.079 ; P=0.008\right)$. However, in both these regressions, the $\mathrm{r}^{2}$ value was low, indicating a weak relationship.

\section{DISCUSSION}

In the current study, the period of energy restriction commenced at d 80 and 100 precalving for primi- and multiparous animals, respectively. During this period, primi- and multiparous animals were offered different dietary regimens. The treatments were designed to represent commercial practices in grassland regions of the United Kingdom and Ireland. After drying-off, high-yielding dairy cows are usually housed during the dry period to allow BCS to be monitored and improved before parturition. However, primiparous animals do not normally need to gain body condition during the precalving period and producers often keep such animals on grass for as long as possible, housing them only about $3 \mathrm{wk}$ before their expected calving date. Because first-calving animals are immature and inherently different in many ways to multiparous animals, this confounding was deemed reasonable.

\section{Dietary Effects on Body Energy Status Precalving}

The current study was undertaken to compare the effects of 2 contrasting levels of precalving nutrition

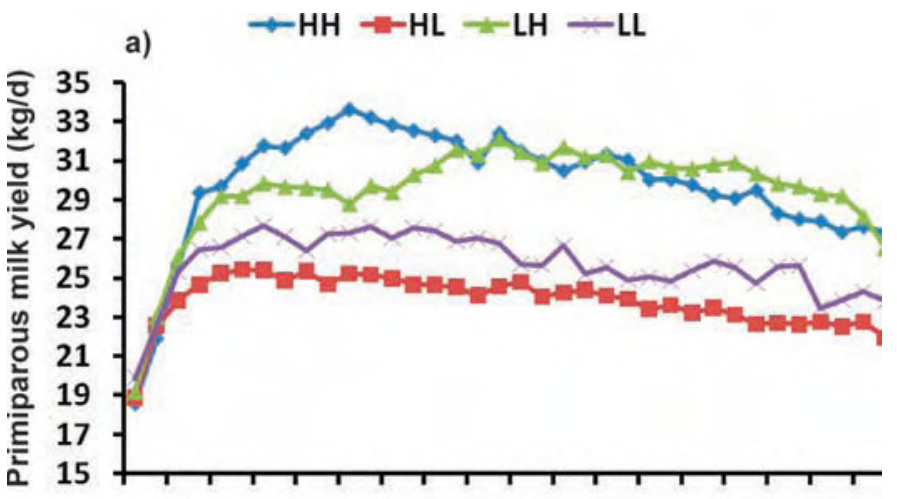

1357911131517192123252729313335 Week of lactation

b)

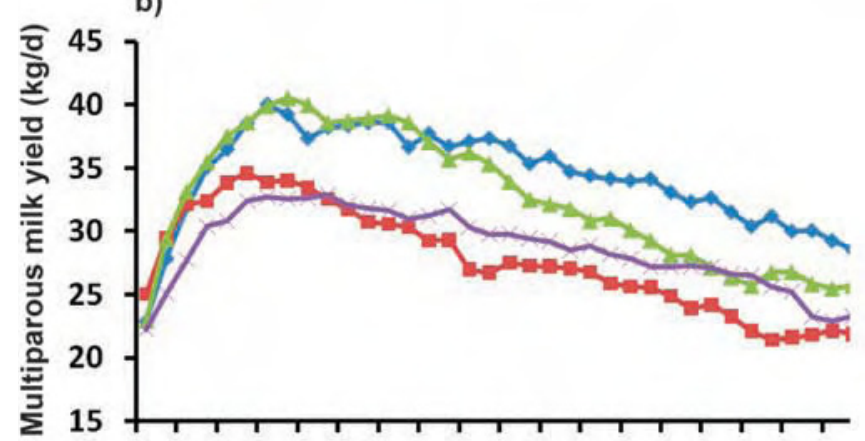

1357911131517192123252729313335

Week of lactation

Figure 2. Milk yields of animals offered 2 levels of energy intake (high and low), pre- and postcalving: $\mathrm{HH}=$ high energy (E) precalving, high $\mathrm{E}$ postcalving; HL = high $\mathrm{E}$ precalving, low $\mathrm{E}$ postcalving; $\mathrm{LH}=$ low $\mathrm{E}$ precalving, high $\mathrm{E}$ postcalving; $\mathrm{LL}=$ low $\mathrm{E}$ precalving, low $\mathrm{E}$ postcalving. Postcalving effects in primiparous animals: precalving treatment, $P=0.42$ (SED, 1.27); postcalving treatment, $P<0.001$ $(\mathrm{SED}, 1.27)$; week of lactation $\times$ precalving treatment $\times$ postcalving treatment, $P<0.001$ (SED, 1.80). Postcalving effects in multiparous animals: precalving treatment, $P=0.88$ (SED, 1.49); postcalving treatment, $P<0.001$ (SED, 1.49); week of lactation $\times$ precalving treatment $\times$ postcalving treatment, $P<0.001$ (SED, 2.32). Color version available in the online PDF.

(a restricted low energy diet vs. an ad libitum high energy diet) on the BCS at calving and postcalving performance of high-yielding dairy cows. It was further designed to examine how, and to what degree, preand postcalving nutrition influence the trajectory of changes in energy-related parameters in high-yielding dairy cows during lactation.

Although the high E and low E diets adopted succeeded in establishing a 0.34-unit difference in BCS at calving in multiparous animals, no significant difference in BCS at calving was found in primiparous animals. This may have been because primiparous animals, when offered a low E diet precalving, suffered less of a restriction in DMI during the precalving period before 


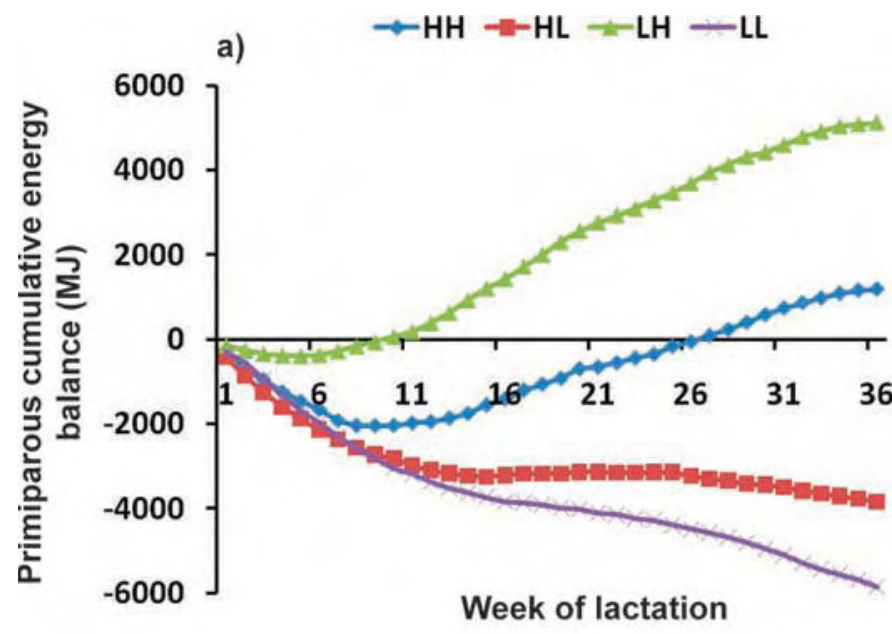

b)

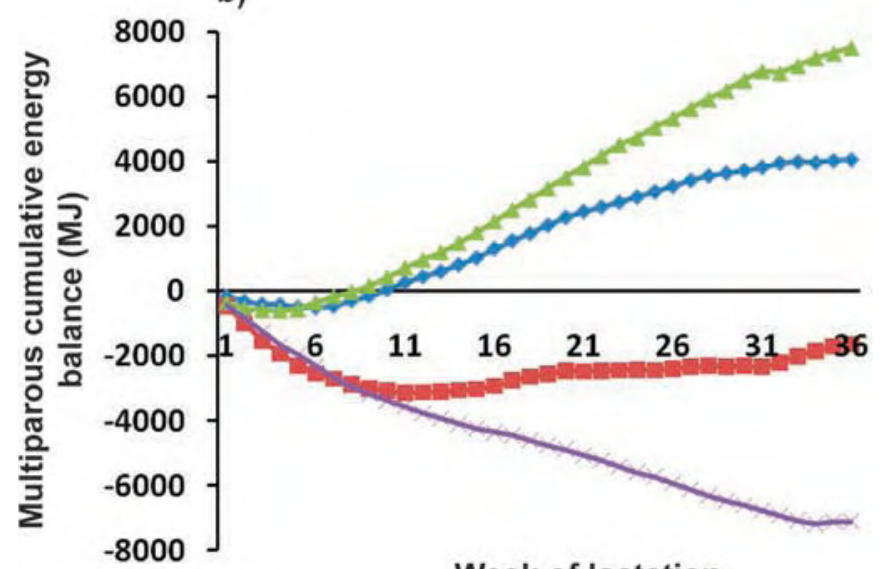

Week of lactation

Figure 3. Cumulative energy balance of animals offered 2 levels of energy intake (high and low), pre- and postcalving: $\mathrm{HH}=$ high energy (E) precalving, high $\mathrm{E}$ postcalving; $\mathrm{HL}=$ high $\mathrm{E}$ precalving, low $\mathrm{E}$ postcalving; $\mathrm{LH}=$ low $\mathrm{E}$ precalving, high $\mathrm{E}$ postcalving; $\mathrm{LL}=$ low E precalving, low E postcalving. Postcalving effects in primiparous animals: precalving treatment, $P=0.06$ (SED, 678 ); postcalving treatment, $P<0.001$ (SED, 678); week of lactation $\times$ precalving treatment $\times$ postcalving treatment, $P<0.001$ (SED, 979). Postcalving effects in multiparous animals: precalving treatment, $P=0.76$ (SED, 974); postcalving treatment, $P<0.001$ (SED, 974); week of lactation $\times$ precalving treatment $\times$ postcalving treatment, $P<0.001$ (SED, 1,433). Color version available in the online PDF.

housing, which was reflected in a difference in BCS at calving of only 0.16 units in the current study. In support of this explanation, precalving treatment had no effect on the DMI of primiparous animals during the last $21 \mathrm{~d}$ of gestation. Overall, the relatively small differences incurred in BCS at calving between precalving treatments in primi- and multiparous animals highlights the difficulty in achieving large changes in BCS of high-yielding dairy cows during their precalving period. This concurs with the view of Friggens et al. (2004b), who presented a strong correlation between

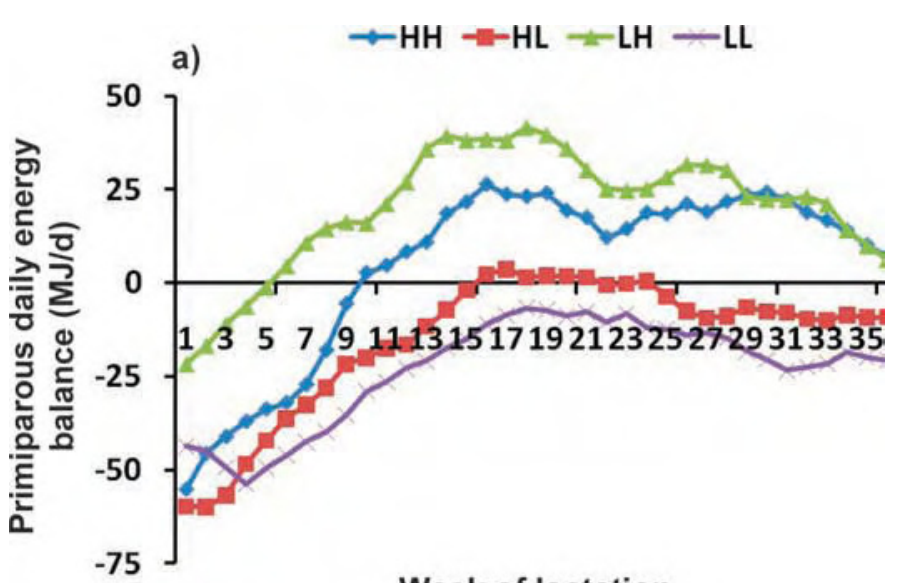

Week of lactation

b)

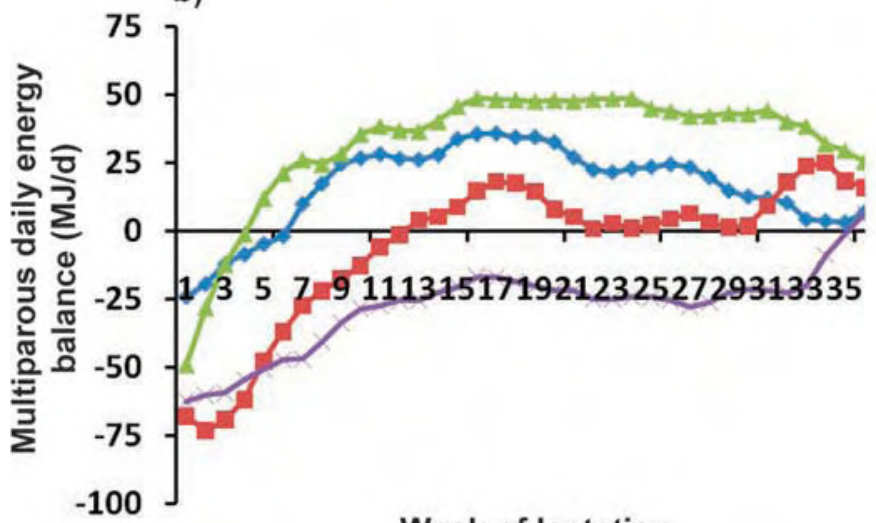

Week of lactation

Figure 4. Daily energy balance of animals offered 2 levels of energy intake (high and low), pre- and postcalving: $\mathrm{HH}=$ high energy (E) precalving, high $\mathrm{E}$ postcalving; $\mathrm{HL}=$ high $\mathrm{E}$ precalving, low E postcalving; $\mathrm{LH}=$ low E precalving, high E postcalving; LL = low E precalving, low E postcalving. Postcalving effects in primiparous animals: precalving treatment, $P=0.17$ (SED, 5.22); postcalving treatment, $P<0.001$ (SED, 5.22); week of lactation $\times$ precalving treatment $\times$ postcalving treatment, $P=0.41$ (SED, 11.0). Postcalving effects in multiparous animals: precalving treatment, $P=0.87$ (SED, 7.4); postcalving treatment, $P<0.001$ (SED, 7.4); week of lactation $\times$ precalving treatment $\times$ postcalving treatment, $P<0.001$ (SED, 14.1). Color version available in the online PDF.

BCS at drying-off and BCS at calving and argued that the strategy of using dry period nutrition as a mechanism to markedly change BCS is unlikely to succeed. A highly significant positive relationship between BCS at drying-off and BCS at calving was also identified in the current experiment.

In the current experiment, multiparous animals offered high $\mathrm{E}$ and low $\mathrm{E}$ diets precalving consumed, on average, 116.3 and $72.6 \mathrm{MJ} / \mathrm{d}$, respectively, from $\mathrm{d}-21$ until calving. Similarly, the difference in DEB of these animals ( -21 to $0 \mathrm{~d}$ postcalving) was $41.1 \mathrm{MJ} / \mathrm{d}$. Over $21 \mathrm{~d}$, this equates to theoretical difference in BCS of 0.48 units (1,770 MJ/unit of BCS loss; AFRC, 1993) com- 
Table 7. Effect of pre- and postcalving diets on blood and liver parameters from d 1 to 100 of lactation ${ }^{1}$

\begin{tabular}{|c|c|c|c|c|c|c|c|c|c|c|c|}
\hline \multirow{2}{*}{ Item } & & & & & \multirow{2}{*}{ SED } & \multicolumn{6}{|c|}{$P$-value } \\
\hline & \multicolumn{4}{|c|}{ Dietary regimen (precalving/postcalving) ${ }^{2}$} & & \multicolumn{3}{|c|}{ Treatment } & \multicolumn{3}{|c|}{ Interaction $^{3}$} \\
\hline \multicolumn{12}{|l|}{ Primiparous } \\
\hline Plasma NEFA $(\mathrm{mEq} / \mathrm{L})$ & 0.44 & 0.45 & 0.37 & 0.41 & 0.032 & 0.006 & 0.26 & $<0.001$ & 0.57 & 0.71 & 0.74 \\
\hline Plasma glucose $(\mathrm{mmol} / \mathrm{L})$ & 3.54 & 3.51 & 3.66 & 3.54 & 0.060 & 0.06 & 0.10 & $<0.001$ & 0.34 & 0.76 & 0.84 \\
\hline Serum IGF-1 (ng/mL) & 109 & 100 & 121 & 98 & 8.6 & 0.29 & $<0.001$ & 0.20 & 0.46 & 0.64 & 0.29 \\
\hline Serum leptin $(\mathrm{ng} / \mathrm{mL})$ & 1.34 & 1.58 & 1.18 & 0.96 & 0.190 & 0.22 & 0.76 & 0.78 & 0.08 & 0.81 & 0.99 \\
\hline Liver triacylglycerol $(\mathrm{mg} / \mathrm{g})$ & 5.27 & 8.32 & 5.92 & 4.64 & 4.000 & 0.56 & 0.70 & $<0.001$ & 0.37 & 0.99 & 0.46 \\
\hline \multicolumn{12}{|l|}{ Multiparous } \\
\hline Plasma NEFA (mEq/L) & 0.34 & 0.42 & 0.29 & 0.35 & 0.046 & 0.09 & 0.02 & $<0.001$ & 0.94 & 0.58 & 0.72 \\
\hline Plasma glucose $(\mathrm{mmol} / \mathrm{L})$ & 3.48 & 3.29 & 3.55 & 3.37 & 0.063 & 0.14 & $<0.001$ & $<0.001$ & 0.96 & 0.15 & 0.54 \\
\hline Plasma urea $(\mathrm{mmol} / \mathrm{L})$ & 5.82 & 7.22 & 5.67 & 6.83 & 0.202 & 0.06 & $<0.001$ & 0.001 & 0.50 & 0.31 & 0.78 \\
\hline
\end{tabular}

${ }^{1}$ Blood parameters were based on weekly sampling; liver parameters were based on mean of 4 samples from 4 animals on each treatment.

${ }^{2} \mathrm{HH}=$ high energy $(\mathrm{E})$ precalving, high E postcalving; $\mathrm{HL}=$ high E precalving, low E postcalving; LH = low E precalving, high E postcalving; $\mathrm{LL}=$ low E precalving, low E postcalving.

${ }^{3}$ Interactions 1,2 , and $3=$ pre- $\times$ postcalving treatment, precalving treatment $\times$ week of lactation, and postcalving treatment $\times$ week of lactation, respectively.

${ }^{4}$ Time $=$ week of lactation.

pared with an actual difference of 0.34 units achieved from d -100 to 0 precalving. Interestingly, Garnsworthy (2006) stated that Holstein cows have more internal fat relative to external (subcutaneous) fat compared with cows of other dairy and beef breeds, suggesting that at equal BCS, a modern Holstein cow will have a greater variance in total body fat content compared with cows from other dairy breeds. Accordingly, a relatively small difference in BCS at calving could reflect a larger difference in total body fat reserves.

\section{Dietary Effects on Production Parameters}

The positive effects of feeding a low E precalving diet on postcalving $\mathrm{BW}$ in primiparous animals can be partly attributed to the degree of BW gain in late gestation. In the last 3 wk of gestation, the BW gain in animals offered high $\mathrm{E}$ and low $\mathrm{E}$ precalving diets was 16.4 and $24.2 \mathrm{~kg}$, resulting in mean precalving BW of 554 and $572 \mathrm{~kg}$, respectively. In contrast, Grummer et al. (1995) reported that primiparous animals on a high plane of nutrition precalving had higher precalving BW than animals on a control diet. In addition to a lower BW precalving, primiparous animals offered a high $\mathrm{E}$ diet precalving had a higher degree of BW loss in early lactation. In the first $12 \mathrm{wk}$ of lactation, the mean daily BW losses for animals on high $\mathrm{E}$ and low $\mathrm{E}$ precalving diets were 0.17 and $0.03 \mathrm{~kg} / \mathrm{d}$, respectively. In support of this, the mean DEB during this period for animals offered high E and low E precalving diets were -30.1 and $-18.2 \mathrm{MJ} / \mathrm{d}$, respectively (Figure 4). In contrast, Grummer et al. (1995) found no effect of precalving treatment on postcalving BW in primiparous animals. However, Keady et al. (2001) found that offering $5 \mathrm{~kg}$ of concentrates daily to primi- and multiparous animals during the last $28 \mathrm{~d}$ of gestation increased BW loss in the first 12 wk of lactation above that sustained by animals offered no concentrates (0.33 vs. $0.04 \mathrm{~kg} / \mathrm{d}$ of BW loss for 5 vs. $0 \mathrm{~kg} / \mathrm{d}$ concentrate, respectively). These are similar to the findings from the current study in primiparous animals; however, Keady et al. (2001) saw no effect of parity on postcalving BW loss. Precalving treatment had no significant effect on the postcalving BW of multiparous animals in the current study.

In the current study, no significant effect of precalving treatment on ME intake or DMI occurred during the postcalving period. This is in agreement with the observations of Holcomb et al. (2001), Keady et al. (2001), and Agenäs et al. (2003). However, Garnsworthy and Topps (1982) stated that increased BCS at calving will suppress DMI following parturition. In the current study, a more pronounced effect might have been observed had the differences in BCS at calving been greater. The trajectory of ME intake in Figure 1 would suggest only minimal effects of precalving nutrition on postcalving ME intake. However, in primipa- 
rous animals a significant precalving treatment $\times$ week of lactation interaction occurred (Table 5), whereby animals allotted to the low E precalving treatment had $30 \mathrm{MJ}$ higher ME intake at the beginning of lactation. A significant precalving treatment $\times$ week of lactation interaction for postcalving BCS was also apparent in both primi- and multiparous animals. Both primi- and multiparous animals offered the low E precalving diet had lower BCS losses postcalving than did animals offered the high E precalving diet. Primiparous animals offered a low E precalving diet sustained a much flatter BCS trajectory than those offered the high E precalving diet.

McNamara et al. (2003) observed a higher postcalving milk yield (wk 1 to 8 ) in multiparous animals offered a high plane of nutrition precalving but no significant difference was found in milk yield between multiparous animals offered high $\mathrm{E}$ or low $\mathrm{E}$ diets precalving in the current study. However, precalving treatment did affect the milk yield trajectory as a significant 3 -way interaction (week of lactation $\times$ precalving treatment $\times$ postcalving treatment) existed for milk yield in both primiand multiparous animals, with the effect of precalving treatment on the milk yield trajectory becoming more pronounced as lactation advanced (Figure 2). In both primi- and multiparous animals, a high E precalving diet negatively affected milk yield in animals offered a low E diet postcalving. This treatment group (HL) experienced excessive NEB in early lactation (Figure 4), which could impair liver function (van den Top et al., 1995) and, thus, milk production, if an accumulation of TAG occurred. The data presented in Table 7 suggest that liver TAG concentrations were indeed high in animals within this treatment group, especially in primiparous animals.

Postcalving, a high E diet increased DMI and milk yield, in agreement with the findings of Agnew et al. (1996) and Kuoppala et al. (2004). In the current study, concentrate was offered as part of a TMR and animals offered high E and low E consumed, on average, 12.4 and $4.4 \mathrm{~kg}$ of DM concentrates/d (1 to $250 \mathrm{~d}$ ), respectively. In the current study, this equates to a milk yield response of $0.61 \mathrm{~kg}$ per $\mathrm{kg} \mathrm{DM}$ of concentrate offered above $4.4 \mathrm{~kg}$. In a study by Sutton et al. (1996), a milk yield response of $0.25 \mathrm{~kg}$ for each $\mathrm{kg} \mathrm{DM}$ of extra concentrate was noted. However, in that study, the concentrate $\mathrm{CP}$ concentrations used were lower than in the current study. In the current study, an increase in the concentrate allocation decreased milk fat concentrations and increased milk protein concentrations, in agreement with research by Friggens et al. (1998) but in contrast to work by Kuoppala et al. (2004). The latter authors reported no significant effects on milk

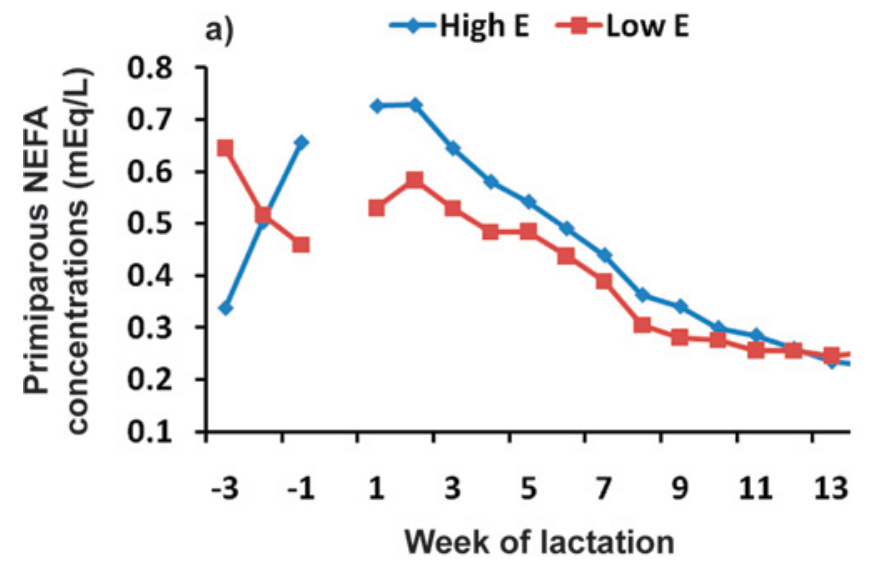

b)

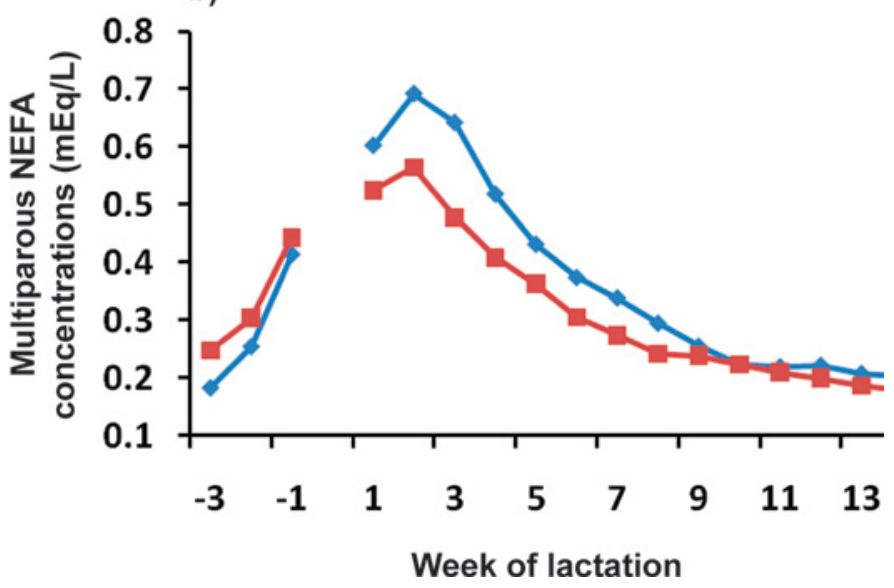

Figure 5. Concentrations of NEFA in animals offered 2 levels of energy intake (high $\mathrm{E}$ and low $\mathrm{E}$ ) precalving. Precalving effects in primiparous animals: precalving treatment, $P=0.21$ (SED, 0.06); precalving treatment $\times$ week precalving, $P<0.001$ (SED, 0.072). Postcalving effects in primiparous animals: precalving treatment, $P=0.006$ (SED, 0.023), precalving treatment $\times$ week of lactation, NS (SED, 0.071). Precalving effects in multiparous animals: precalving treatment, $P=$ 0.10 (SED, 0.032); precalving treatment $\times$ week precalving, $P=0.71$ (SED, 0.045). Postcalving effects in multiparous animals: precalving treatment, $P=0.09$ (SED, 0.032); precalving treatment $\times$ week of lactation, $P=0.85$ (SED, 0.077). Color version available in the online PDF.

composition of increasing the concentrate level from 9 to $14 \mathrm{~kg}$ of $\mathrm{DM} /$ head per day.

\section{Dietary Effects on Energy Status (d 1 to 250)}

Predicting or defining dietary effects on postcalving BCS loss and on subsequent energy status is difficult because multiple factors affect the degree of energy deficit and subsequent BCS loss. The current status (i.e., BCS at calving), and long-term objectives of the individual animal may facilitate the expression of a genetic component to BCS loss which aims to achieve a BCS that is optimal for future reproduction (Frig- 
gens et al., 2004a; Garnsworthy, 2006). Garnsworthy (2006) stated that a target BCS that is optimal for reproduction is genetically predetermined and the rate of BCS loss depends on the cow's current BCS status relative to the genetically predetermined BCS optimal for reproduction. In the current study, DEB and CEB represent daily and total energy deficits which, it is assumed, are buffered by BCS loss. Thus, the difference in DEB between animals on high $\mathrm{E}$ and low $\mathrm{E}$ precalving treatments, but within the same postcalving regimen, should represent a genetic component to BCS loss (Figure 4). That is, animals with high BCS at calving will be further from the optimal BCS for reproduction, so that a higher proportion of BCS loss may originate from genetic control compared with animals with a low BCS at calving. However, in early to mid lactation, a period when the dairy cow is under a heavy energy demand, there is, undoubtedly, environmentally driven tissue mobilization (BCS loss) that exceeds the genetically determined rate. Environmentally driven mobilization can be influenced by diet and subsequently has the potential to alter the energy trajectory of these animals. Despite the small difference in BCS at calving in the current study, the existence of a 3-way interaction for CEB (week of lactation $\times$ precalving treatment $\times$ postcalving treatment; Figure 3 ) in both primi- and multiparous animals suggests that precalving dietary regimen has a significant influence on the energy profile of high-yielding dairy animals. This interaction may be a result of the unsustainability of the high rate of BCS loss observed in animals offered the HL diet. An extremely high rate of mobilization in this early period can cause TAG accumulation in the liver, which may impair liver function and be detrimental to other body functions including milk production (van den Top et al., 1995). A reduction in milk production will reduce the requirement for mobilization, allowing an improvement in energy balance to be achieved. Animals on the LL diet did not respond in a similar manner and remained in severe NEB throughout. It has been suggested that, despite the obvious negative effects of NEB, the duration of NEB alone is not a sufficiently good indicator of unsustainable metabolic load (Pryce and Løvendahl, 1999; Thomas et al., 1999). Accordingly, prolonged periods of mild NEB may not negatively affect milk production.

From parturition onward, DEB values were used to calculate $\mathrm{CEB}$, which represents an absolute change in overall energy status. When considering actual CEB values, the mean CEB at wk 36 of lactation for multiparous animals on the LH and HL treatments were 7,507 and $-7,103 \mathrm{MJ}$, respectively. This difference $(14,610$ MJ) equates to a hypothetical difference in BCS of 8.3 units (1,770 MJ/unit of BCS loss; AFRC, 1993), or a hypothetical difference in BW of $624 \mathrm{~kg}(23.4 \mathrm{MJ} / \mathrm{kg}$ of BW loss (AFRC, 1990). The actual BW difference between animals in these 2 treatment groups was $39 \mathrm{~kg}$ at wk 36 of lactation with an actual BCS difference of 0.49 units. The discrepancies in CEB may be partly a result of assumptions used in the energy calculations. These assumptions include the following: (1) the maintenance requirement of all animals is a constant value that is relative to metabolic BW, irrespective of the level of production; (2) the net efficiency of energy utilization for lactation $\left(\mathrm{k}_{1}\right)$ does not fall below 0.59 despite being partially scaled to level of intake (Thomas, 2004); and (3) all dietary energy intake is partitioned toward maintenance and milk yield.

Energy requirements for maintenance $\left(\mathrm{ME}_{\mathrm{m}}\right)$ represent a substantial proportion of total energy requirements and have first priority in energy partitioning to maintain essential metabolic processes and tissue integrity (Kirkland, 2000). It is likely that $\mathrm{ME}_{\mathrm{m}}$ is not a constant, but is influenced by the level of intake (Ketelaars and Tolkamp, 1992; Kirkland, 2000) and by the milk production potential (Ferrell and Jenkins, 1984).

Despite having some degree of flexibility, the limited scaling of net efficiency of energy use for milk production to the level of intake may distort calculations of energy status. As ME intake increases, the net efficiency of energy utilization for milk production $\left(\mathrm{k}_{\mathrm{l}}\right)$ will decrease below the base value of 0.59 (T. Yan, Agri-Food \& Biosciences Institute, Northern Ireland, personal communication) because of an increase in the energy requirement of processes related to the digestion of food (Van Es and Van der Honing, 1979).

The assumption that ME intake is partitioned only between maintenance and milk production may also have a significant bearing on the energy trajectory. Garnsworthy (2006) reported that maintenance or gain of BW may occur while body reserves decline, and attributed this to a gut fill. This increase in BW could also be attributed to an increase in gut development (after a precalving suppression) and to body protein accretion.

\section{Precalving and Postcalving Dietary Effects on Plasma NEFA Concentrations}

Douglas et al. (2006) noted that reduced feed intake in the dry period increased NEFA concentrations in the blood prepartum and resulted in lower liver lipid content postpartum. In the current study, plasma NEFA concentrations in primi- and multiparous animals were not significantly affected by precalving treatment during the last 3 wk of gestation. However, Figure 5 illustrates a significant difference in plasma NEFA concentrations between precalving treatments in primiparous animals 
at wk 3 before calving, with high $\mathrm{E}$ and low E precalving diets generating concentrations of 0.34 and 0.79 (SED $=0.105)$, respectively. Precalving NEFA concentrations in primiparous animals were higher $(0.51 \mathrm{mEq} / \mathrm{L})$ in the current study than in previous studies (e.g., 0.30 $\mathrm{m} M$ in Meikle et al., 2004; and $0.25 \mathrm{~m} M$ in Douglas et al., 2006). However, Vandehaar et al. (1999) and Meikle et al. (2004) reported higher precalving NEFA concentrations in primiparous animals than in multiparous animals, in agreement with the current study.

In the current study, primiparous animals receiving a high E precalving diet had higher plasma NEFA concentrations during the postcalving period than those receiving a low $\mathrm{E}$ precalving $\operatorname{diet}(0.44$ vs. 0.38; SED $=0.022)$, whereas only a tendency $(P=0.09)$ was observed for lower plasma NEFA concentrations in multiparous animals offered the low E precalving diet (Figure 5). Dann et al. (2006) stated that dietary restriction compared with ad libitum access to feed in the close-up precalving period did not affect serum NEFA concentrations postcalving. In agreement with this, primiparous animals offered a low E diet precalving ( $-21 d$ to parturition) in the current study had similar DMI during the last $21 \mathrm{~d}$ of gestation and yet precalving treatment had a significant effect on postcalving plasma NEFA concentrations. This suggests that energy allocation during the far-off period ( -80 to -21 d precalving) had a greater influence on plasma NEFA concentrations postcalving than during the close-up period. Body reserve mobilization during the dry period is hypothesized to prepare the cow for a period of energy deficit in early lactation by conditioning the liver to cope more efficiently and effectively with the increase in blood NEFA concentrations that occurs during this period (Friggens et al., 2004b).

\section{CONCLUSIONS}

Allocating high-genetic-merit Holstein-Friesian animals to either a high $\mathrm{E}$ or low $\mathrm{E}$ precalving dietary regimen significantly affected mean BCS during the precalving period. However, between-treatment differences in BCS in both primiparous and multiparous animals were small. Attempting to substantially alter BCS during the dry period is a difficult task and should be addressed well in advance of drying off. Feeding a low E precalving diet significantly reduced BCS loss postcalving (reflected by changes in plasma NEFA concentrations) and supported a more rapid return to positive energy status in animals offered a high plane of nutrition postcalving. This suggests that initiating BCS loss during the dry period reduces mobilization postpartum and conditions the liver to better deal with higher NEFA concentrations in early lactation. Postcalving, a low plane of nutrition was detrimental to both milk production and energy balance, and is not suitable for the high-yielding dairy cow. With regard to the assessment of energy status, it is likely that both a cow's maintenance requirements and the net efficiency of energy utilization for milk production vary with the level of ME intake and production. However, energetic responses to high $\mathrm{E}$ and low $\mathrm{E}$ diets pre- and postcalving in the current study highlight the importance of addressing a dairy cow's energy status precalving as well as during early lactation.

\section{ACKNOWLEDGMENTS}

Thanks are due to the technical staff at AFBI Agriculture Branch, Hillsborough, for their assistance in recording and preparing data sets. The blood metabolite analyses by AFBI Veterinary Sciences Division and hormone analyses by Agriculture Branch (Newforge) are gratefully acknowledged. This study was co-funded by the Department of Agriculture and Rural Development and AgriSearch.

\section{REFERENCES}

Agenäs, S., E. Burstedt, and K. Holtenius. 2003. Effects of feeding intensity during the dry period. 1 . Feed intake, body weight, and milk production. J. Dairy Sci. 86:870-882.

Agnew, K. W., C. S. Mayne, and J. G. Doherty. 1996. An examination of the effect of method and level of concentrate feeding on milk production in dairy cows offered a grass silage-based diet. Anim. Sci. 63:21-35.

Agricultural and Food Research Council (AFRC). 1990. Technical committee on responses to nutrients, report number 5 , nutritive requirements of ruminant animals: Energy. Nutr. Abstr. Rev. Ser. B 60:729-804.

Agricultural and Food Research Council (AFRC). 1993. Energy and protein requirements of ruminants. CAB Int., Wallingford, UK.

Andersen, J. B., D. G. Mashek, T. Larsen, M. O. Nielsen, and K. L. Ingvartsen. 2002. Effects of hyperinsulinaemia under euglycaemic condition on liver fat metabolism in dairy cows in early and mid lactation. J. Vet. Med. A Physiol. Pathol. Clin. Med. 49:65-71.

Cushnahan, A., and F. J. Gordon. 1995. The effects of grass preservation on intake, apparent digestibility and rumen degradation characteristics. Anim. Sci. 60:429-438.

Dann, H. M., N. B. Litherland, J. P. Underwood, M. Bionaz, A. D'Angelo, J. W. McFadden, and J. K. Drackley. 2006. Diets during far-off and close-up dry periods affect periparturient metabolism and lactation in multiparous cows. J. Dairy Sci. 89:3563-3577.

Douglas, G. N., T. R. Overton, H. G. Bateman, H. M. Dann, and J. K. Drackley. 2006. Prepartal plane of nutrition, regardless of dietary energy source, affects periparturient metabolism and dry matter intake. J. Dairy Sci. 89:2141-2157.

Edmonson, A. J., I. J. Lean, L. D. Weaver, T. Farver, and G. Webster. 1989. A body condition scoring chart for Holstein dairy cows. J. Dairy Sci. 72:68-78.

Farm Animal Welfare Council (FAWC). 1997. Page 96 in Report on the Welfare of Dairy Cattle. Farm Animal Welfare Council, Surrey, UK.

Ferrell, C. L., and T. G. Jenkins. 1984. Energy utilisation by mature, non-pregnant, non-lactating dairy cows of different types. J. Anim. Sci. 58:234-243. 
Friggens, N. C., J. B. Andersen, T. Larsen, O. Aaes, and R. J. Dewhurst. 2004b. Priming the dairy cow for lactation: A review of dry cow feeding strategies. Anim. Res. 53:453-473.

Friggens, N. C., G. C. Emmans, I. Kyriazakis, J. D. Oldham, and M. Lewis. 1998. Feed intake relative to stage of lactation for dairy cows consuming total mixed diets with a high or low ration of concentrate to forage. J. Dairy Sci. 81:2228-2239.

Friggens, N. C., K. L. Ingvarsten, and G. C. Emmans. 2004a. Prediction of body lipid change in pregnancy and lactation. J. Dairy Sci. $87: 988-1000$.

Garnsworthy, P. C. 2006. Body condition score in dairy cows: Targets for production and fertility. Pages $61-85$ in Recent Advances in Animal Nutrition. P. C. Garnsworthy and J. Wiseman, ed. Nottingham University Press, Nottingham, UK.

Garnsworthy, P. C., and J. H. Topps. 1982. The effect of body condition of dairy cows at calving on their food intake and performance when given complete diets. Anim. Prod. 35:113-119.

Grummer, R. R., P. C. Hoffman, M. L. Luck, and S. J. Bertics. 1995. Effect of prepartum and postpartum dietary energy on growth and lactation of primiparous cows. J. Dairy Sci. 78:172-180.

Holcomb, C. S., H. H. Van Horn, H. H. Head, M. B. Hall, and C. J. Wilcox. 2001. Effects of prepartum dry matter intake and forage percentage on postpartum performance of lactating dairy cows. J. Dairy Sci. 84:2051-2058.

Ingvarsten, K. L., N. C. Friggens, and P. Faverdin. 1999. Food intake regulation in late pregnancy and early lactation. Pages 37-54 in Metabolic Stress in Dairy Cows. Occasional Publications No. 24 Br. Soc. Anim. Sci., Edinburgh, UK.

Keady, T. W. J., C. S. Mayne, D. A. Fitzpatrick, and M. A. McCoy. 2001. Effect of concentrate feed level in late gestation on subsequent milk yield, milk composition, and fertility of dairy cows. J. Dairy Sci. 84:1468-1479.

Ketelaars, J. J. M. K., and B. J. Tolkamp. 1992. Towards a new theory of food intake regulation in ruminants. Causes of differences in voluntary feed intake: critique of current views. Livest. Prod. Sci. 30:269-296.

Kirkland, R. M. 2000. Energy partitioning and utilisation in lactating dairy cows. PhD Diss. Queen's University, Belfast, UK.

Kokkonen, T., J. Taponen, T. Anttila, L. Syrjälä-Quist, C. Delavaud, Y. Chilliard, M. Tuori, and A. T. Tesfa. 2005. Effect of body fatness and glucogenic supplementation on lipid and protein mobilization and plasma leptin in dairy cows. J. Dairy Sci. 88:1127-1141.

Krebs, M., H. Stingl, P. Nowotny, D. Weghuber, M. Bischof, W. Waldhäusl, and M. Roden. 2000. Prevention of in vitro lipolysis by tetrahydrolipstatin. Clin. Chem. 46:950-954.

Kuoppala, K., S. Yrjänen, S. Jaakkola, J. Kangasniemi Sariola, and H. Khalili. 2004. Effects of increasing concentrate energy supply on the performance of loose-housed dairy cows fed grass silage-based diets. Livest. Prod. Sci. 85:15-26.

McCleary, B. V., V. Solah, and T. S. Gibson. 1994. Quantitative measurement of total starch in cereal flours and products. J. Cereal Sci. 20:51-58.

McMurray, C. H., W. J. Blanchflower, and D. A. Rice. 1984. Automated kinetic method for D-3-hydroxybutyrate in plasmas or serum. Clin. Chem. 30:421-425.

McNamara, S., J. J. Murphy, M. Rath, and F. P. O'Mara. 2003. Effects of different transition diets on energy balance, blood metabolites and reproductive performance in dairy cows. Livest. Prod. Sci. 84:195-206.

Meikle, A., M. Kulcsar, Y. Chilliard, H. Febel, C. Delavaud, D. Cavestany, and P. Chilibroste. 2004. Effects of parity and body condition at parturition on endocrine and reproductive parameters of the cow. Reproduction 127:727-737.

Nielsen, B. L. 1999. Perceived welfare issues in dairy cattle, with special emphasis on metabolic stress. Pages 1-7 in Metabolic Stress in Dairy Cows. Occasional Publications No. 24, Br. Soc. Anim. Sci., Edinburgh, UK
Park, R. S., R. E. Agnew, F. J. Gordon, and R. W. J. Steen. 1998. The use of near infrared reflectance spectroscopy (NIRS) on undried samples of grass silage to predict chemical composition and digestibility parameters. Anim. Feed Sci. Technol. 72:155-167.

Payne, R. W., D. A. Murray, S. A. Harding, D. B. Baird, and D. M. Soutar. 2007. GenStat for Windows. 10th ed. Introduction. VSN International, Hemel Hempstead, UK.

Porter, M. G. 1992. Comparison of sample preparation methods for the determination of the gross energy concentration of fresh silage. Anim. Feed Sci. Technol. 37:201-208.

Porter, M. G., and R. S. Murray. 2001. The volatility of components of grass silage on oven drying and the inter-relationship between dry matter content estimated by different analytical methods. Grass Forage Sci. 56:405-411.

Pryce, J. E., and P. Løvendahl. 1999. Options to reduce vulnerability to metabolic stress by genetic selection. Pages 119-127 in Metabolic Stress in Dairy Cows. Occasional Publications No. 24, Br. Soc. Anim. Sci., Edinburgh, UK.

Ruegg, P. L., and R. L. Milton. 1995. Body condition scores of Holstein cows on Prince Edward Island; relationships with yield, reproductive performance, and disease. J. Dairy Sci. 78:552-564.

Steen, R. W. J. 1989. A comparison of soyabean, sunflower, and fish meals as protein supplements for yearling cattle offered grass silage based diets. Anim. Prod. 48:127-132.

Sutton, J. D., K. Aston, D. E. Beever, and M. S. Dhanoa. 1996. Milk production from grass silage diets: Effects of high protein concentrates for lactating heifers and cows on intake, milk production and milk nitrogen fractions. Anim. Sci. 62:207-215.

Thomas, C. 2004. Feed into milk: An Advisory Manual. Nottingham University Press, Nottingham, UK

Thomas, C., K. A. Leach, D. N. Logue, C. Ferris, and R. H. Phipps 1999. Management options to reduce load. Pages 129-139 in Metabolic Stress in Dairy Cows. Occasional Publications No. 24, Br. Soc. Anim. Sci., Edinburgh, UK.

van den Top, A. M., T. Wensing, M. J. H. Geelen, G. H. Wentink, A. T. van't Klooster, and A. C. Beynen. 1995. Time trends of plasma lipids and enzymes synthesizing hepatic triacylglycerol during postpartum development of fatty liver in dairy cows. J. Dairy Sci. $78: 2208-2220$.

Van Es, A. J. H., and Y. Van der Honing. 1979. Energy utilisation. Pages 68-89 in Feeding Strategy for the High Yielding Dairy Cow. W. H. Broster and H. Swan, ed. Granada Publishing, London, UK

Vandehaar, M. J., G. Yousif, B. K. Sharma, T. H. Herdt, R. S. Emery, M. S. Allen, and J. S. Liesman. 1999. Effect of energy and protein density of prepartum diets on fat and protein metabolism of dairy cattle in the periparturient period. J. Dairy Sci. 82:1282-1295.

Veerkamp, R. F., G. Simm, and J. D. Oldham. 1995. Genotype by environment interactions: Experience from Langhill. Page 21-26 in Breeding and Feeding the High Genetic Merit Dairy Cow. Occasional Publications No. 19, Br. Soc. Anim. Sci. Edinburgh, UK.

Winkelman, L. A., T. H. Elsasser, and C. K. Reynolds. 2008. Limitfeeding a high-energy diet to meet energy requirements in the dry period alters plasma metabolite concentrations but does not affect intake or milk production in early lactation. J. Dairy Sci. 91:1067-1079

Wylie, A. R. G., D. M. B. Chestnut, and D. J. Kilpatrick. 1997. Growth and carcass characteristics of heavy slaughter weight lambs: Effects of sire breed and sex of lamb and relationships to serum metabolites and IGF-1. Anim. Sci. 64:309-318.

Wylie, A. R. G., S. Woods, A. F. Carson, and M. McCoy. 2008. Periprandial changes in metabolite and metabolic hormone concentrations in high-genetic-merit dairy heifers and their relationship to energy balance in early lactation. J. Dairy Sci. 91:577-586.

Young, D. S. 2000. Effects of Drugs on Clinical Laboratory Tests. AACC. 5th ed. American Academy of Clinical Chemistry Press, Washington, DC. 